\title{
Stress and deformation analysis of gob-side pre-backfill driving procedure of longwall mining: a case study
}

\author{
Rui Wu ${ }^{1} \cdot$ Penghui Zhang ${ }^{1} \cdot$ Pinnaduwa H. S. W. Kulatilake $^{1}$ (D) Hao Luo ${ }^{1} \cdot$ \\ Qingyuan $\mathrm{He}^{2}$
}

Received: 10 February 2021/Revised: 31 March 2021 / Accepted: 22 July 2021/Published online: 16 August 2021

(C) The Author(s) 2021

\begin{abstract}
At present, non-pillar entry protection in longwall mining is mainly achieved through either the gob-side entry retaining (GER) procedure or the gob-side entry driving (GED) procedure. The GER procedure leads to difficulties in maintaining the roadway in mining both the previous and current panels. A narrow coal pillar about 5-7 m must be left in the GED procedure; therefore, it causes permanent loss of some coal. The gob-side pre-backfill driving (GPD) procedure effectively removes the wasting of coal resources that exists in the GED procedure and finds an alternative way to handle the roadway maintenance problem that exists in the GER procedure. The FLAC ${ }^{3 D}$ software was used to numerically investigate the stress and deformation distributions and failure of the rock mass surrounding the previous and current panel roadways during each stage of the GPD procedure which requires "twice excavation and mining". The results show that the stress distribution is slightly asymmetric around the previous panel roadway after the "primary excavation". The stronger and stiffer backfill compared to the coal turned out to be the main bearing body of the previous panel roadway during the "primary mining". The highest vertical stresses of 32.6 and $23.1 \mathrm{MPa}$, compared to the in-situ stress of $10.5 \mathrm{MPa}$, appeared in the backfill wall and coal seam, respectively. After the "primary mining", the peak vertical stress under the coal seam at the floor level was slightly higher (18.1 MPa) than that under the backfill (17.8 MPa). After the "secondary excavation", the peak vertical stress under the coal seam at the floor level was slightly lower (18.7 MPa) than that under the backfill (19.8 MPa); the maximum floor heave and maximum roof sag of the current panel roadway were 252.9 and $322.1 \mathrm{~mm}$, respectively. During the "secondary mining", the stress distribution in the rock mass surrounding the current panel roadway was mainly affected by the superposition of the front abutment pressure from the current panel and the side abutment pressure from the previous panel. The floor heave of the current panel roadway reached a maximum of $321.8 \mathrm{~mm}$ at $5 \mathrm{~m}$ ahead of the working face; the roof sag increased to $828.4 \mathrm{~mm}$ at the working face. The peak abutment pressure appeared alternately in the backfill and the coal seam during the whole procedure of "twice excavation and mining" of the GPD procedure. The backfill provided strong bearing capacity during all stages of the GPD procedure and exhibited reliable support for the roadway. The results provide scientific insight for engineering practice of the GPD procedure.
\end{abstract}

Keywords Gob-side pre-backfill driving procedure $\cdot$ Floor heave $\cdot$ Roadway stability $\cdot$ Stress distribution $\cdot$ Abutment pressure

Pinnaduwa H. S. W. Kulatilake

kulatila@arizona.edu

$1 \quad$ School of Resources and Environmental Engineering, Jiangxi University of Science and Technology, Ganzhou 341000, China

2 State Key Laboratory of Coal Resources and Safe Mining, School of Mines, China University of Mining and Technology, Xuzhou 221116, China

\section{Introduction}

Coal will be the main energy source in China for a long time in the future. At present, the annual output accounts for $70 \%$ of the primary energy supply (Liu and Wang 2017). Even though the demand for coal is high, unfortunately, the recovery rate of coal in coal mines in China is 
only about $30 \%-50 \%$ on the average (Yuan 2017,2018 ). In the traditional coal mining technology, 20-30 m wide coal pillars are often left, which wastes resources greatly. Therefore, improving recovery rate of coal and prolonging service lives of coal mines have become major research issues (Ju et al. 2019; Zhao and Li 2018; Wang et al. 2020; Sajjad et al. 2019). To eliminate the issue of coal mining with large pillars, the non-pillar coal mining technology has been suggested. At present, mainly two methods of non-pillar coal mining exist: the gob-side entry driving (GED) procedure and the gob-side entry retaining (GER) procedure.

As shown in Fig. 1a, in the GER procedure, a backfill wall is constructed at the edge of the goaf behind the working face while the working face is advanced during mining of the previous panel. Through this way the roadway is maintained for the tailgate of the working face associated with the next adjacent panel. The technology results in non-pillar mining and reduces the number of roadway excavations.

The basic procedure of the GED method is to leave a narrow coal pillar at the edge of the abandoned entry and the stable goaf, and drive a gob-side entry, as the roadway, along the edge of the narrow coal pillar (5-7 m) as shown in Fig. 1b. During the roadway excavation in the GED procedure, the narrow coal pillar becomes a rib pillar with the same function as the backfill wall in the GER procedure. The side abutment pressure is transferred deeper to

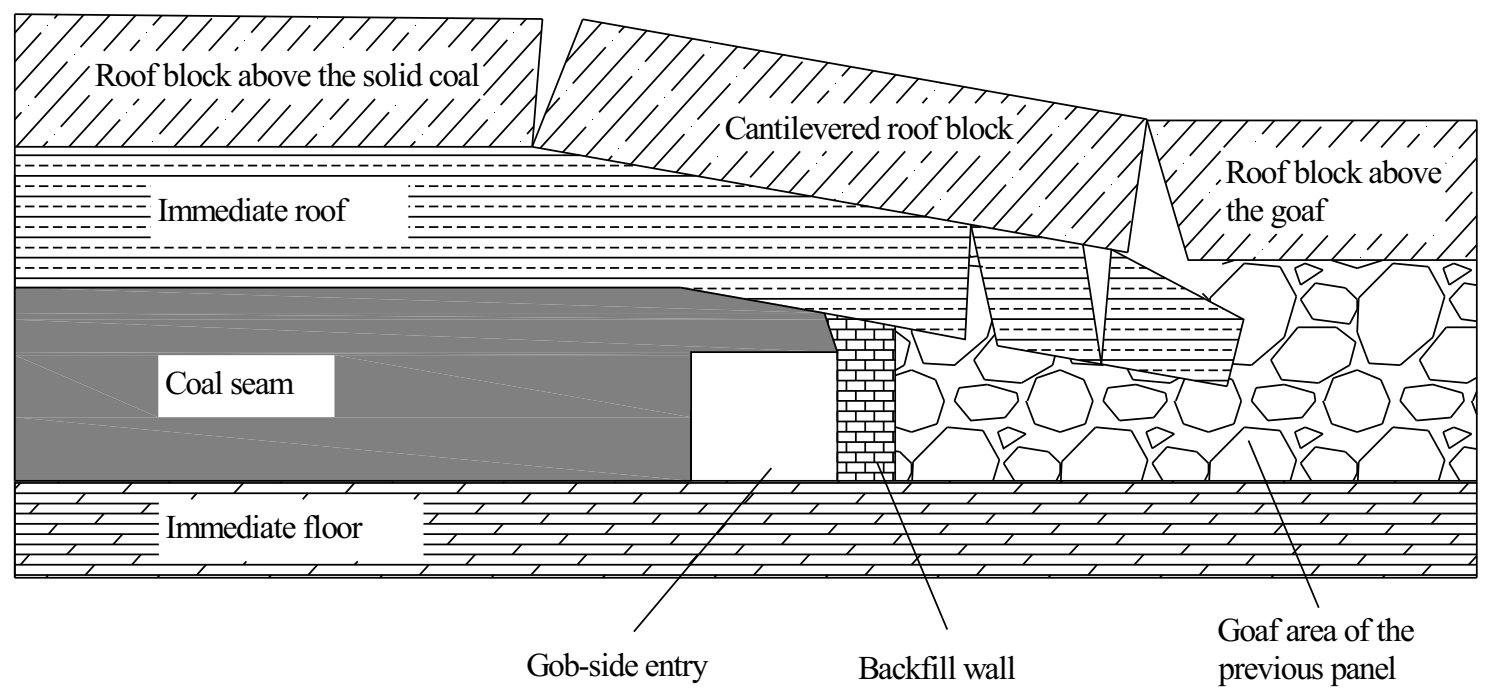

(a) Sketch for the GER procedure

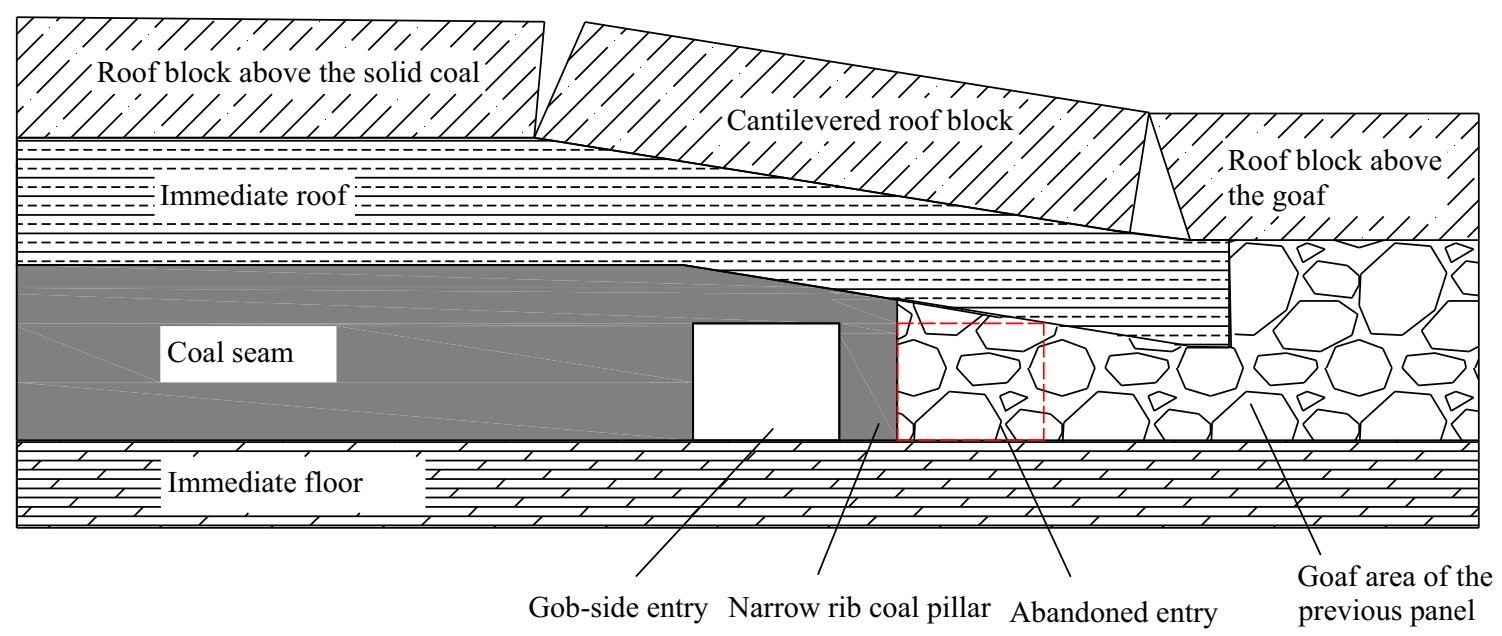

(b) Sketch for the GED procedure

Fig. 1 Sketches to illustrate the main components of the gob-side entry retaining (GER) and gob-side entry driving (GED) procedures 
the coal measure rocks. It not only improves the recovery rate of coal resources, but also reduces the high stress concentration, which improves the working condition.

Since the procedures of the GER and GED can effectively avoid leaving large coal pillars and improve the recovery rate, those methods have been widely used since they were suggested in the 1950s (Hua 2006). These technologies proved to be successful and extended the lifecycle of mines (Tan et al. 2016). Many scholars have performed research on the GER and GED methods using different perspectives. In the GER and GED procedures, during the excavation and mining, the stability of the surrounding rock is affected by several factors (Han et al. 2019; Jiang et al. 2016; Liu et al. 2009). Also, asymmetric deformations appear under dynamic conditions (Fan et al. 2014). In the GER and GED procedures, the size of the coal pillar (or the width of the backfill wall) and the angle of the cantilevered roof block have a great influence on the stress distribution in the surrounding rock (Wu et al. 2019; Zha et al. 2017; Chang et al. 2018; Feng and Wang 2020). Analysis, monitoring, and control of the stability of the surrounding rock can not only ensure the safety of mining, but also can greatly improve the recovery rate (Wang et al. 2012; Zhang et al. 2015). During the excavation, the roof goes through various stages of deformation. A reasonable breaking location of the main roof, stress and deformation analyses and monitoring can ensure the stability of the roadway (Wang and Gao 2019; Tan et al. 2015; Huang et al. 2018; Yang et al. 2019).

Floor heave is also an inevitable problem in both the GER and GED procedures. During the "primary mining", the mechanism of the roadway floor heave is mainly caused by the bearing capacity failure and swelling instability (Mo et al. 2019). With the increase of the swelling coefficient, the floor heave of the roadway is significantly enhanced, but its convergent deformation rate decreases (Tang and Tang 2012). Floor heave restricts the popularization and use of the GER and GED procedures (Xu et al. 2015). Therefore, floor heave prevention is one of the important topics that need to be addressed. At present, automated roadway excavation and non-pillar mining are also used in several mines (Zhang et al. 2015; Wang et al. 2018; Zhu et al. 2019). However, typically a certain width of coal pillar is retained in the GED procedure, which is not a complete non-pillar mining technology.

Although the issue of leaving a large coal pillar can be eliminated by using the GER or GED procedure, each of the procedures still has some shortcomings. The roadway in the GER procedure experiences mining influences twice; therefore, the roadway maintenance is difficult, and the cost of roadway support is high, especially in thick coal seams. The current panel roadway in the GED procedure is excavated on the side where the side abutment pressure of the previous panel is less, and the roadway only undergoes one mining influence. Compared to the GER procedure, the roadway is easier to maintain in the GED procedure. However, the GED procedure does not provide non-pillar mining and it requires a narrow coal pillar of about 5-7 m width; therefore, in the case of thick coal seams, more coal resources are lost (loss of about 2\%-3\%) in the GED procedure.

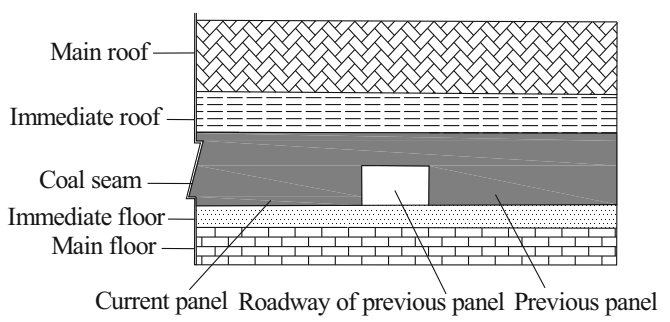

(a) Previous panel roadway driving associated with "primary excavation"

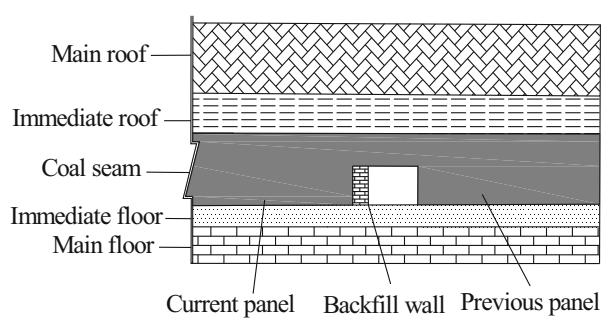

(b) Pre-backfilling associated with "primary excavation"

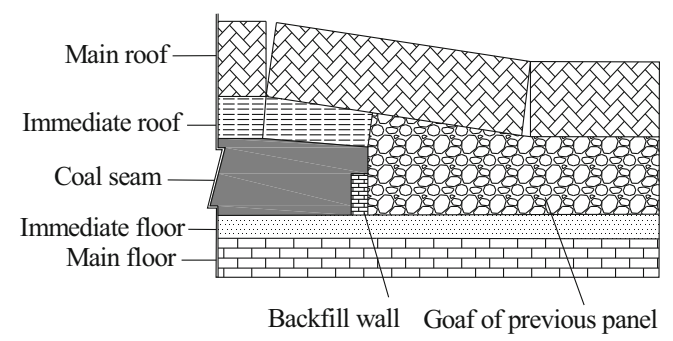

(c) Previous panel mining ("primary mining")

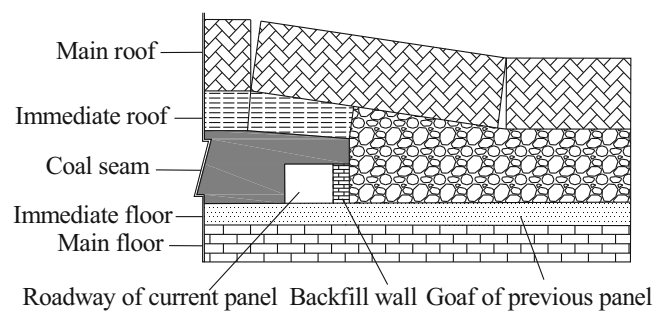

(d) Roadway driving along the backfill

for current panel ("secondary excavation")

Fig. 2 Steps of the gob-side pre-backfill driving (GPD) procedure prior to "secondary mining". Note: See Fig. $3 \mathrm{~b}$ for the "secondary mining" 


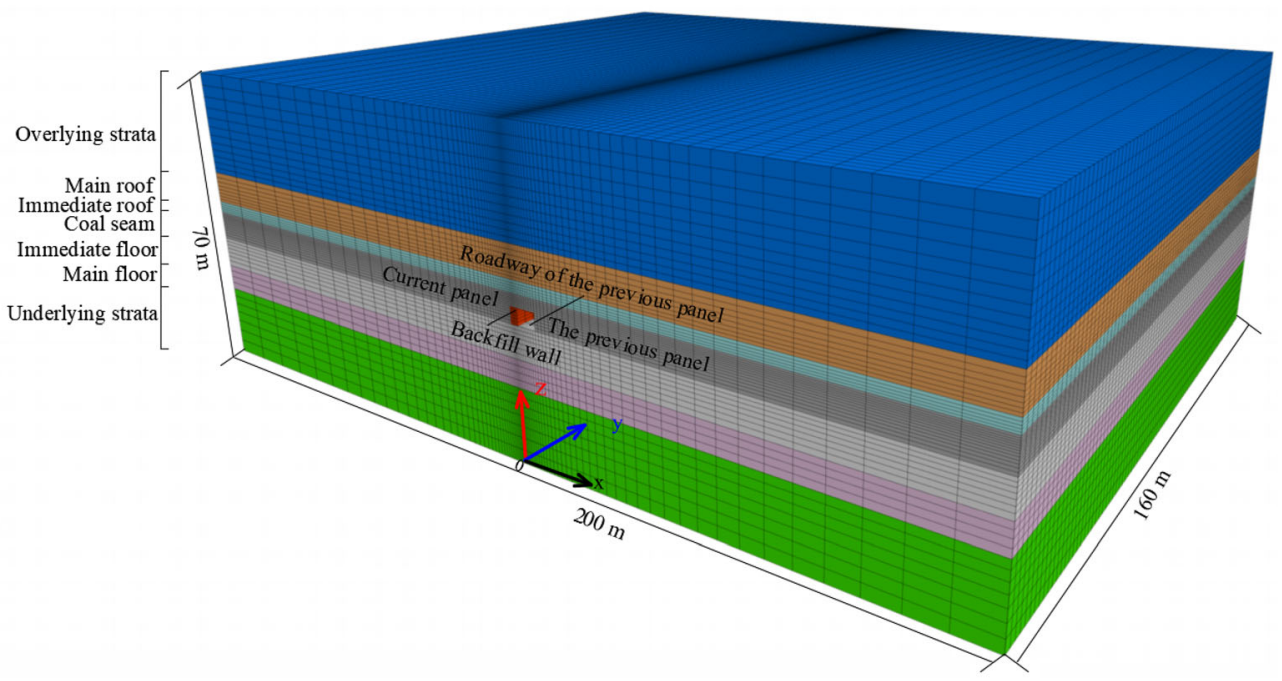

(a) Model for the "primary excavation"

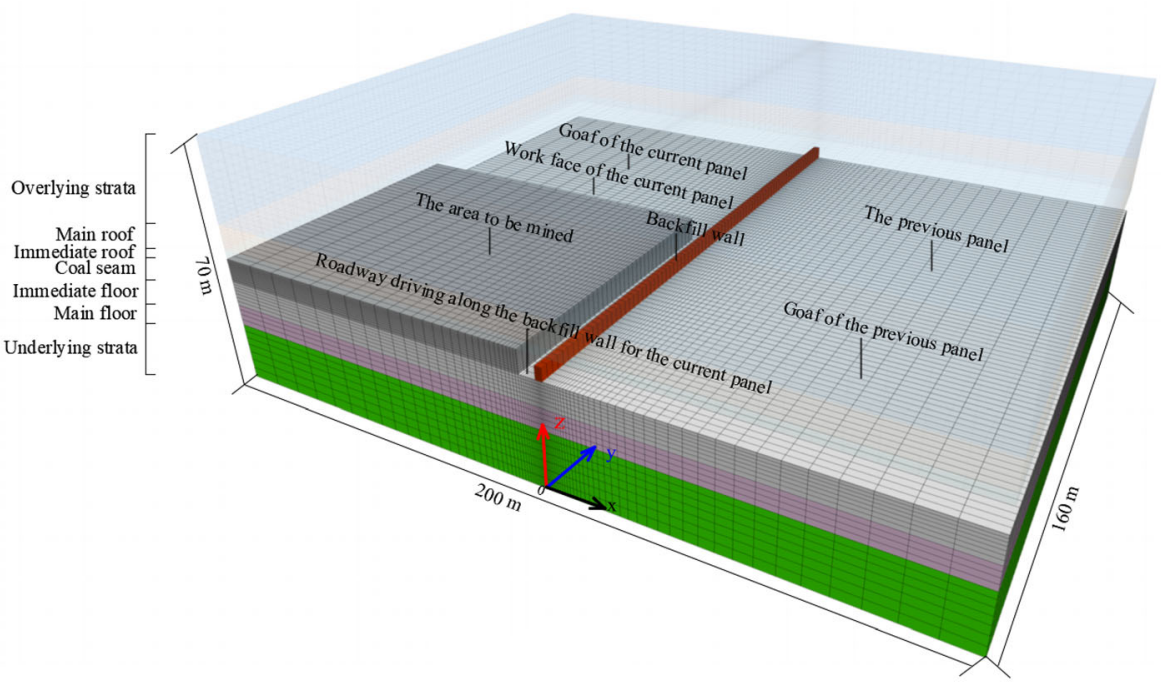

(b) Model for the "secondary mining"

Fig. 3 Set up of the FLAC ${ }^{3 \mathrm{D}}$ model for the first (primary excavation) and last (secondary mining) stages. Notes: The mining shown on the left side of $\mathbf{b}$ is the "secondary mining"

Therefore, some researchers have investigated the possibility of implementing the relatively new gob-side prebackfill driving (GPD) procedure, which means replacing the coal pillar with a pre-backfill wall to realize real nonpillar mining (Zhang et al. 2010; Wu et al. 2017, 2018). The GPD procedure can save coal resources and realize non-pillar mining. Procedures of the GPD are shown in Figs. 2 and 3. The backfill wall width should be decided in advance when driving the roadway of the previous panel (Fig. 2a). The backfill wall of the same height as of that of the roadway is built as shown in Fig. 2b. It is worth noting that the excavation of the roadway of the previous panel and the construction of the backfill are treated under the "primary excavation" step of the GED procedure in the paper. The backfill wall is constructed at the edge of the coal seam behind the working face while the working face is advanced during the excavation of the roadway for the previous panel. When the previous panel is mined, which is considered as the "primary mining" step of the GED procedure in the paper, the main roof rotates and sinks (Fig. 2c). After the primary mining, when the movement of overlying strata has stopped and basically a stable stage has been reached, the current panel roadway driving along the backfill is performed (Fig. 2d). This step is considered as 
the "secondary excavation" of the GED procedure in the paper. This excavated roadway then can be used as a ventilation or a transportation route for the current panel. Finally, the current panel mining is done as shown in Fig. 3b. This is considered as the "secondary mining" step of the GED procedure in the paper.

At present, most of the research on the GPD procedure is focused on the stability of the roof, the backfill wall and on the coal side of the roadway, and some achievements have been made (Wu et al. 2017, 2018). Both the backfill side and the coal side of the roadway are always in the state of high pressure after the roadway excavation; therefore, investigations should be conducted to evaluate this high pressure. In addition, research is lacking on the stress evolution and deformation mechanism of the floor under the high pressure of the two sides of the GPD method.

Based on the afore-mentioned facts, this paper investigates the stress and deformation including the failure zones of the rock mass surrounding the roadways, with emphasis on the floor of a coal mine during the whole procedure of "twice excavation and mining" of the GPD method. The evolution mechanisms of the stress and deformations of the floor under the backfill and coal seam, and around the roadways are obtained. These findings are expected to provide important information to control the stability of the rock mass with emphasis on the floor of the GPD method.

\section{Geological conditions}

Changcun coal mine is located in Changzhi City, Shanxi Province, and it is a modern large mine. The average thickness of the main mining layer (No. 3 coal seam) is around $6.1 \mathrm{~m}$ with a high mining pressure and the coal seam is soft. The aquifer present in the upper part of No. 3 coal seam is a weak aquifer, and the water from the aquifer has little influence on the roadway excavations and mining of the panels. The depth of the coal seam is $423-470 \mathrm{~m}$, and its average depth is around $450 \mathrm{~m}$. The inclination angle of the coal seam is $0^{\circ}-6^{\circ}$. Table 1 provides the mechanical property values of the coal seam, the overlying and underlying coal measure rocks, and the backfill material. These values represent mass properties for different material and were obtained from the technical staff of the mine through personal communication. For more

Table 1 Physical and mechanical parameter values of the coal, coal measure rocks and the backfill material

\begin{tabular}{|c|c|c|c|c|c|c|c|c|c|}
\hline $\begin{array}{l}\text { Rock and } \\
\text { coal strata }\end{array}$ & Lithology & $\begin{array}{l}\text { Thickness } \\
\text { (m) }\end{array}$ & $\begin{array}{l}\text { Tensile } \\
\text { strength } \\
(\mathrm{MPa})\end{array}$ & $\begin{array}{l}\text { Uniaxial } \\
\text { compressive } \\
\text { strength (MPa) }\end{array}$ & $\begin{array}{l}\text { Density } \\
\left(\mathrm{kg} / \mathrm{m}^{3}\right)\end{array}$ & $\begin{array}{l}\text { Young's } \\
\text { modulus } \\
(\mathrm{GPa})\end{array}$ & $\begin{array}{l}\text { Poisson's } \\
\text { ratio }\end{array}$ & $\begin{array}{l}\text { Cohesion } \\
\text { (MPa) }\end{array}$ & $\begin{array}{l}\text { Angle of } \\
\text { internal } \\
\text { friction }\left(^{\circ}\right)\end{array}$ \\
\hline \multirow{4}{*}{$\begin{array}{l}\text { Overlying } \\
\text { strata }\end{array}$} & Mudstone & 4.80 & 2.20 & 9.4 & 2400 & 17 & 0.24 & 0.40 & 38 \\
\hline & $\begin{array}{l}\text { Fine } \\
\quad \text { sandstone }\end{array}$ & 7.10 & 5.80 & 19.2 & 2600 & 15 & 0.25 & 3.20 & 40 \\
\hline & Mudstone & 4.30 & 2.20 & 9.4 & 2400 & 17 & 0.24 & 0.40 & 38 \\
\hline & $\begin{array}{l}\text { Sandy- } \\
\text { mudstone }\end{array}$ & 11.00 & 3.50 & 10.5 & 2450 & 12 & 0.26 & 0.50 & 39 \\
\hline \multirow[t]{3}{*}{ Main roof } & Siltstone & 3.40 & 3.10 & 11.3 & 2500 & 26 & 0.23 & 5.00 & 38 \\
\hline & $\begin{array}{l}\text { Medium- } \\
\text { sandstone }\end{array}$ & 1.30 & 5.80 & 19.2 & 2600 & 15 & 0.25 & 3.20 & 40 \\
\hline & Siltstone & 2.80 & 3.10 & 11.3 & 2500 & 26 & 0.23 & 5.00 & 38 \\
\hline $\begin{array}{l}\text { Immediate } \\
\text { roof }\end{array}$ & Mudstone & 3.40 & 2.20 & 9.4 & 2400 & 17 & 0.24 & 0.40 & 38 \\
\hline Coal seam & $\begin{array}{l}\text { No. } 3 \text { Coal } \\
\text { seam }\end{array}$ & 6.10 & 1.40 & 3.14 & 1400 & 2 & 0.38 & 1.62 & 36 \\
\hline $\begin{array}{c}\text { Backfill } \\
\text { wall }\end{array}$ & $\begin{array}{l}\text { Concrete } \\
\text { Grade } \\
\text { C30 }\end{array}$ & 3.50 & 1.45 & 30 & 2370 & 30 & 0.20 & 3.18 & 55 \\
\hline \multirow{3}{*}{$\begin{array}{l}\text { Immediate } \\
\text { floor }\end{array}$} & Mudstone & 0.90 & 2.20 & 9.4 & 2400 & 17 & 0.24 & 0.40 & 38 \\
\hline & $\begin{array}{l}\text { Fine } \\
\text { sandstone }\end{array}$ & 1.00 & 5.80 & 19.2 & 2600 & 15 & 0.25 & 3.20 & 40 \\
\hline & Mudstone & 5.50 & 2.20 & 9.4 & 2400 & 17 & 0.24 & 0.40 & 38 \\
\hline Main floor & Siltstone & 6.20 & 3.10 & 11.3 & 2500 & 26 & 0.23 & 5.00 & 38 \\
\hline
\end{tabular}


information on possible different backfill material the reader is referred to Tan et al. $(2015,2016)$.

\section{Setup of the numerical model}

Figure 3 shows the FLAC ${ }^{3 \mathrm{D}}$ model of the GPD method for the first (primary excavation) and the last (secondary mining) stages, respectively. The dimensions of the model are $200 \mathrm{~m} \times 160 \mathrm{~m} \times 70 \mathrm{~m}$ and the 3-D model is divided into 520,000 elements and 556,308 nodes (see Fig. 3a). The $X-Y-Z$ rectangular coordinate system used is shown in Fig. 3. The roadway shown in Fig. $3 b$ is the one corresponding to the current panel. The roadway floor along the backfill is located at the height of $Z=30 \mathrm{~m}$ of the model, and the elemental discretization applied in the model is shown in Fig. 3. The stratigraphy and applied boundary conditions are shown in Fig. 4. The elastic-perfect plastic constitutive model is used for the coal, coal measure rock masses and the backfill material shown in the numerical model. The Mohr-Coulomb failure criterion with tension cut-off is used as the shear strength criterion for the coal and coal measure rock masses, and the backfill layer. The physical and mechanical properties of the coal, different coal measure rock masses shown on the stratigraphy and the backfill material are given in Table 1. The mining depth is about $450 \mathrm{~m}$, and a $9.54 \mathrm{MPa}$ compressive stress boundary condition is applied to the top surface of the numerical model to simulate the overburden stress (assuming the density of the overburden strata as $2400 \mathrm{~kg} /$ $\mathrm{m}^{3}$ ). A lateral coefficient of 0.47 (Kang et al. 2010) is applied in the $X$ and $Y$ directions to simulate the two horizontal stresses. The size of the roadway of the current panel is $4.5 \mathrm{~m}$ wide and $3.5 \mathrm{~m}$ height, and it is not supported. The width of the backfill is $1.6 \mathrm{~m}$, and its material is the industrial cement with the grade of $\mathrm{C} 30$ having a compressive strength of $30 \mathrm{MPa}$.

\section{Stress and failure zone analyses around the previous panel roadway during "primary excavation and mining"}

\subsection{Stress distribution in the rock mass surrounding the previous panel roadway after the "primary excavation"}

It is noted that the primary excavation analysis includes the previous panel roadway excavation shown in Fig. 2a and the pre-built backfill shown in Fig. 2b. In the field, first, a certain length of the roadway is excavated, and it is left without any rock support for a certain time duration and then it is supported. After that, the backfill wall is constructed for a part of the rock supported section. This

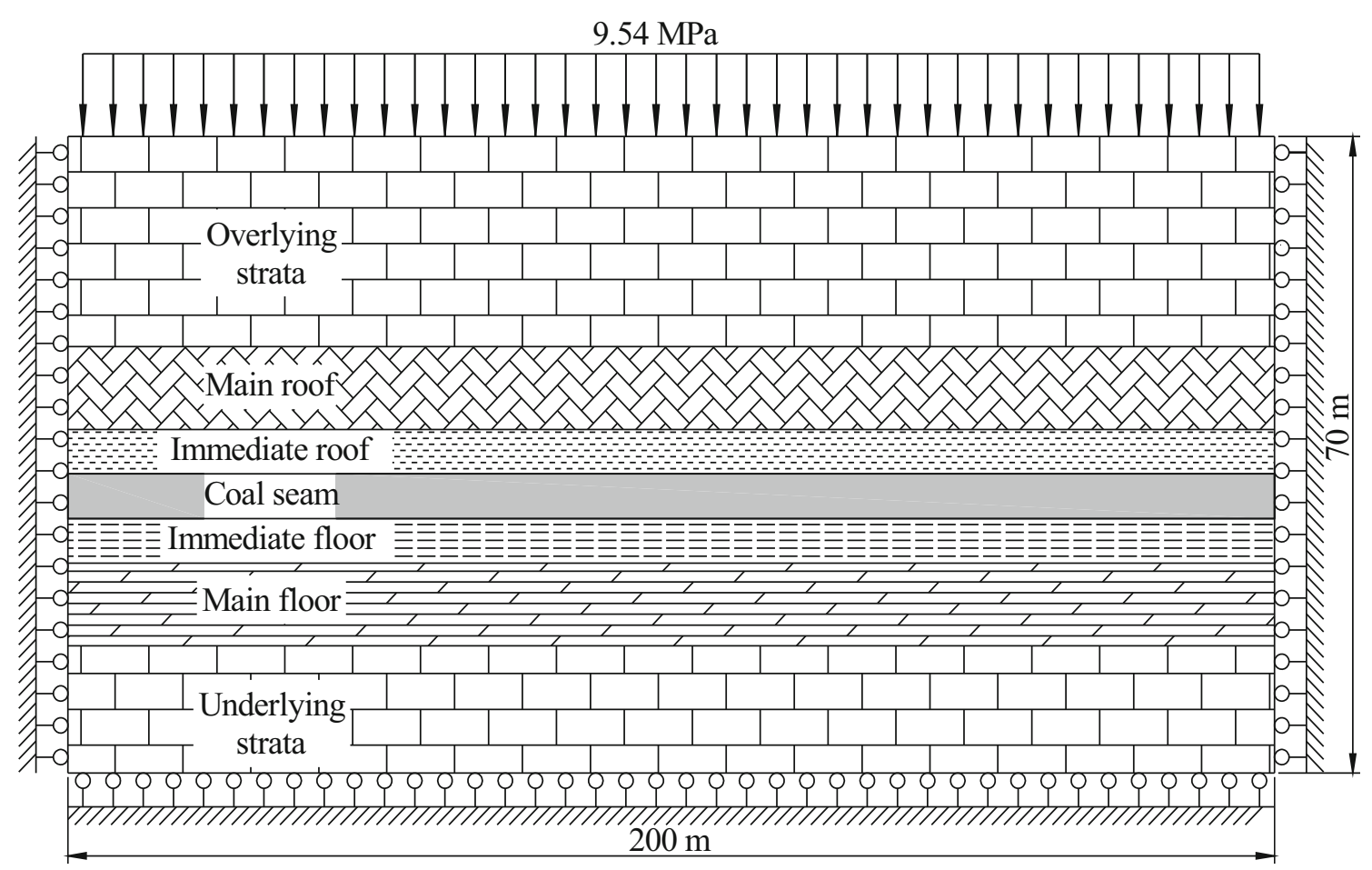

Fig. 4 Stratigraphy and boundary conditions of the FLAC ${ }^{3 \mathrm{D}}$ numerical model 
procedure is repeated in several increments in the field until the primary excavation is fully completed. It is important to note that the rock deformation is a time dependent process, and it is controlled by the rheological properties of the rocks and the properties of the rock supports. It is very difficult or almost impossible to monitor the stresses and deformations that take place in the roadway during these operations. Thus, it is almost impossible to simulate all these operations in a numerical model accurately. These difficulties led to simulation of the worst-case scenario in the numerical model. Primary excavation was conducted after including the backfill wall without any rock support.

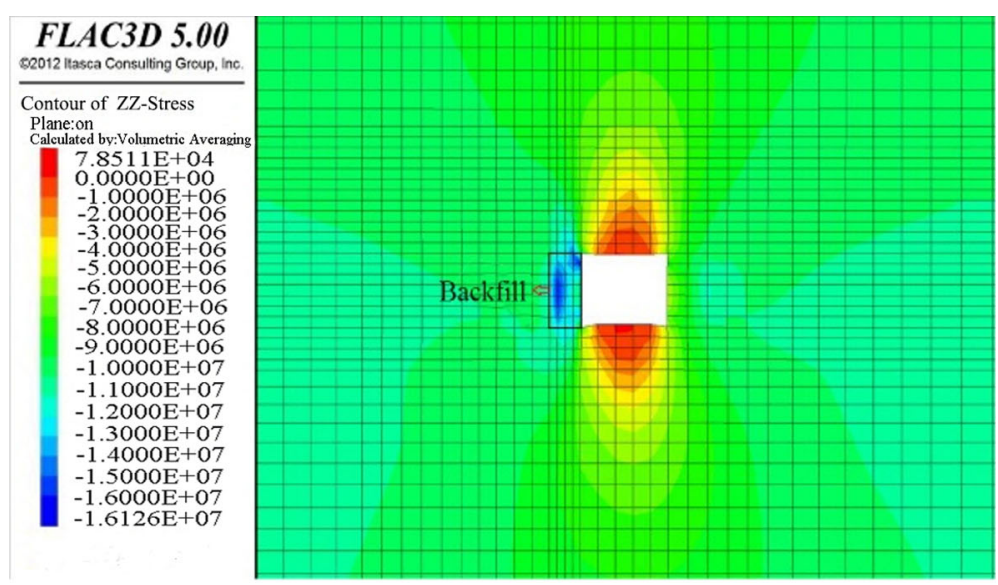

(a) Vertical stress

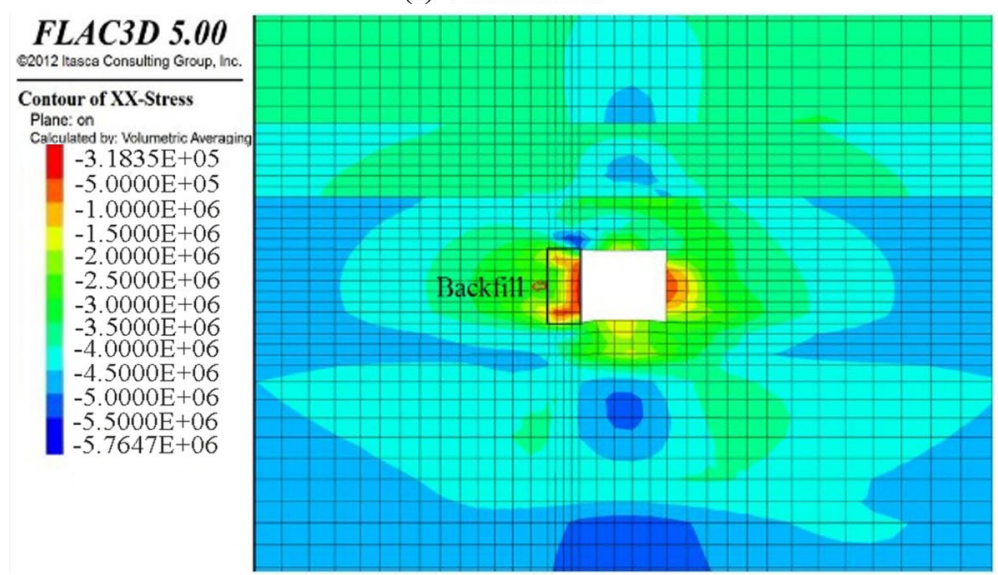

(b) Horizontal stress

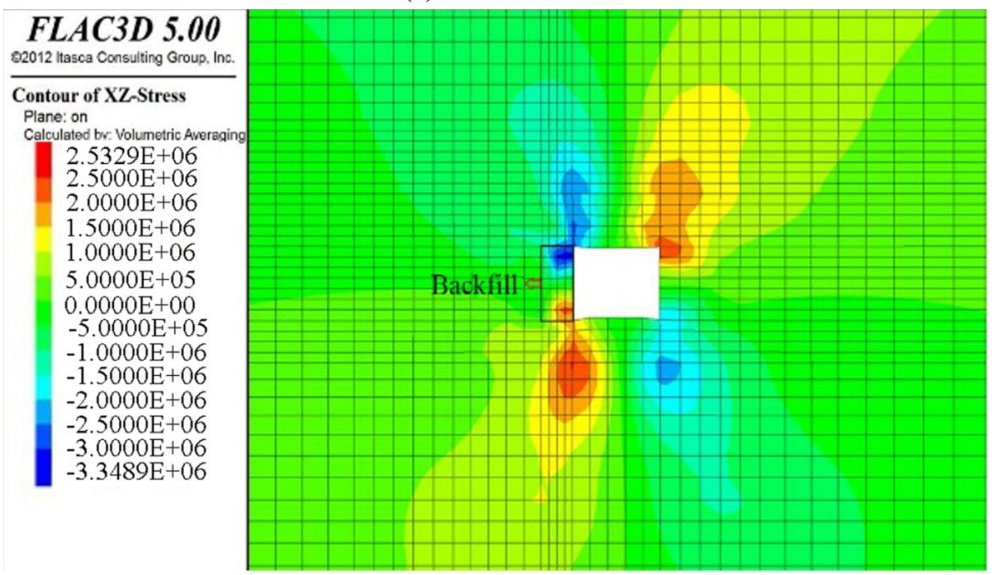

(c) Shear stress

Fig. 5 Stress distributions in the rock masses surrounding the previous panel roadway after the "primary excavation" 


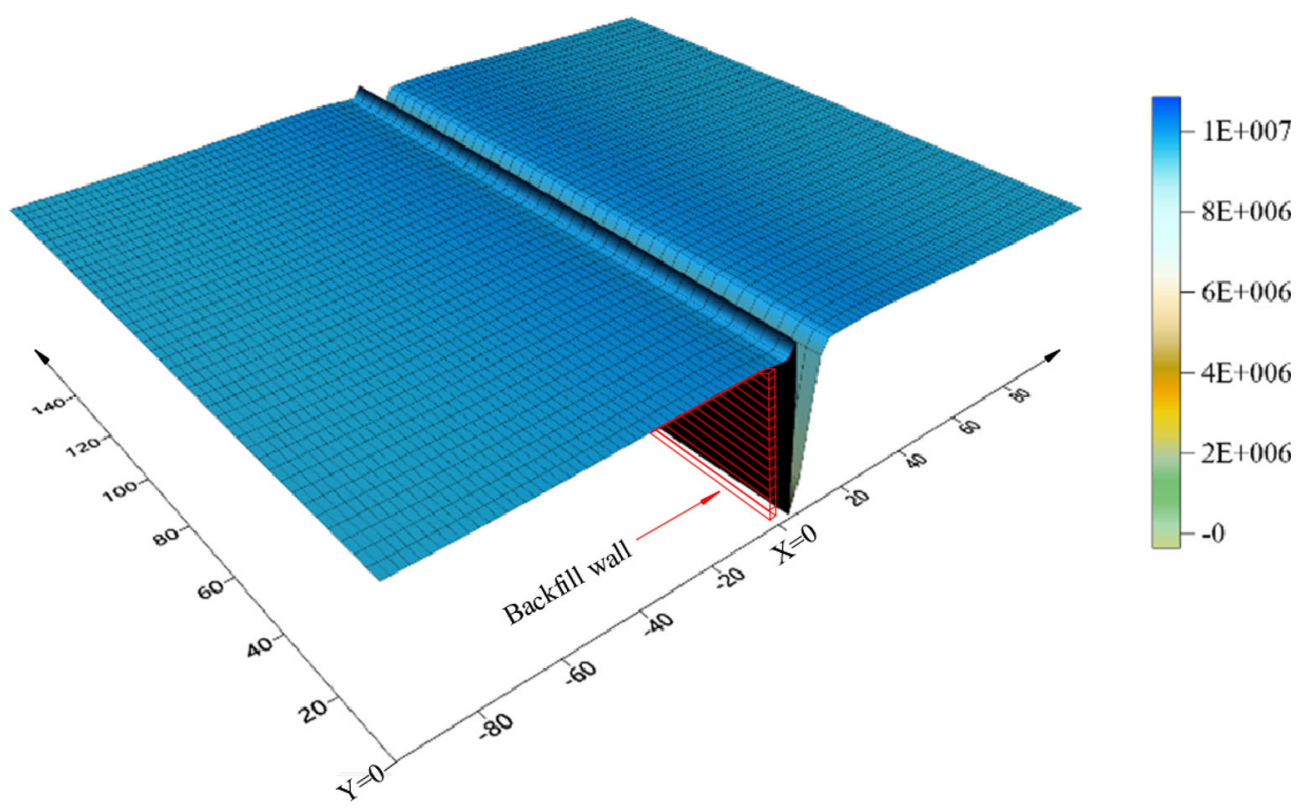

(a) Vertical stress distribution at the immediate floor level (the values are given in $\mathrm{Pa}$ )

\section{FLAC3D 5.00 \\ O2012 ltasca Consulting Group, Inc.

Zone
Plane: on
Colorby: State -Average
None
shear-n shear-p
shear-n shear-p tension-p
shear-p
shear-p tension-p
tension-n shear-p tension-p
tension-p

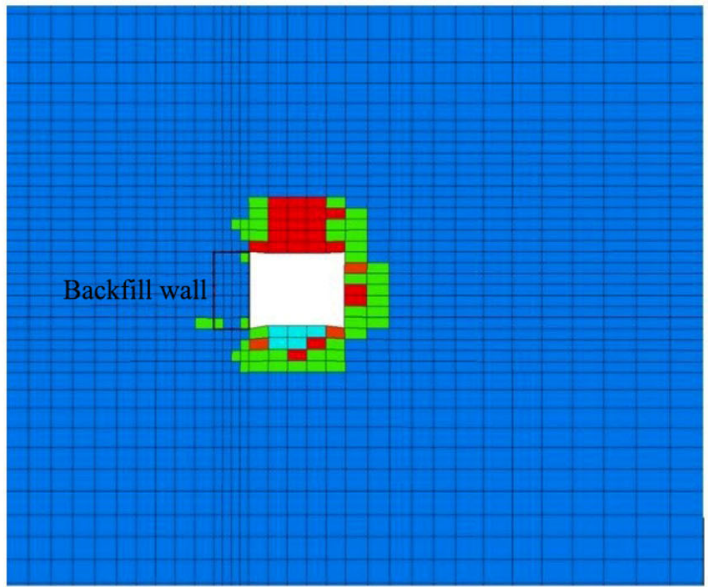

(b) Failure zone distribution

Fig. 6 Vertical stress distribution at the immediate floor level and failure zone distribution around the previous panel roadway after the "primary excavation"

To represent the backfill wall, the coal that exists in the area was replaced by the backfill material. In other words, for the numerical simulation, the coal properties were replaced by the backfill material properties for the included backfill wall area. In the field, the stresses acting on the backfill wall result from the stress relaxation that occurs after installation of the backfill wall in the incremental construction. Because the worst-case scenario is used in the numerical model, the values obtained in the numerical model may be expected to be higher than that in the field. The difference depends on the time left between the roadway excavation and backfill wall construction in the incremental construction and on whether the rock support was applied or not after the roadway excavation.

The stability of the previous panel roadway is mainly affected by the stress acting on the coal side (right side from the roadway in Fig. 5) and the backfill side (left side from the roadway in Fig. 5) and on the deformation distribution. The backfill is the main bearing wall during the stable period of the "primary excavation". Figure 5 shows the stress on the backfill and in the rock mass around the previous panel roadway after the "primary excavation" (Fig. $2 \mathrm{~b}$ shows the primary excavation configuration). The stresses clearly show an asymmetric distribution around the 


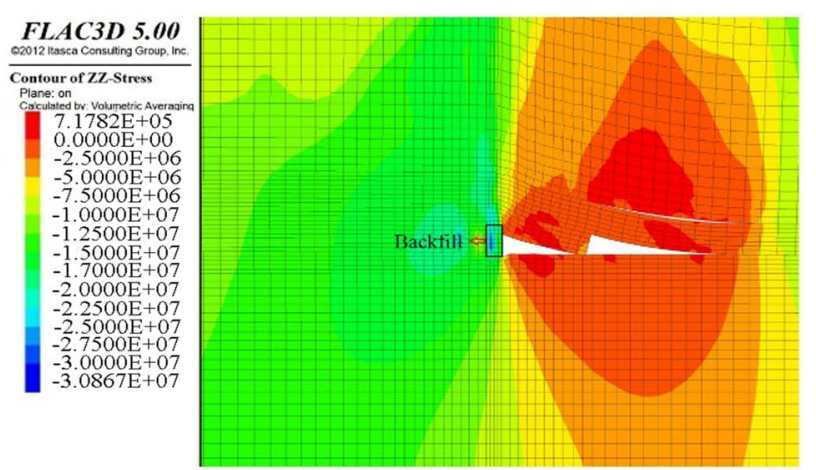

(a) Vertical stress

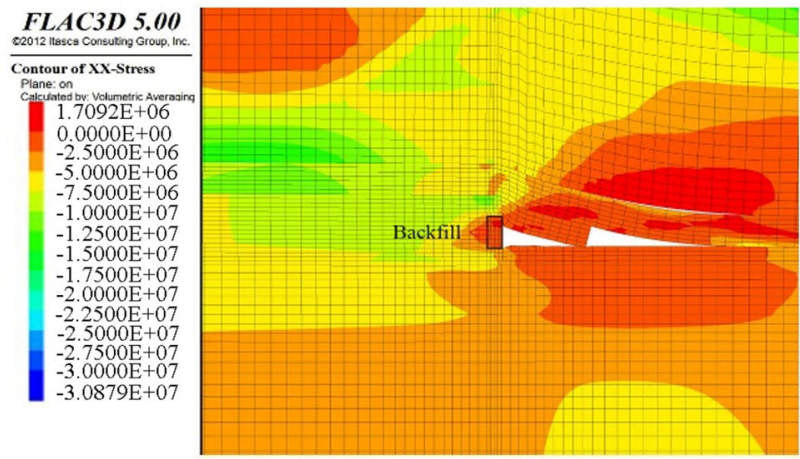

(b) Horizontal stress

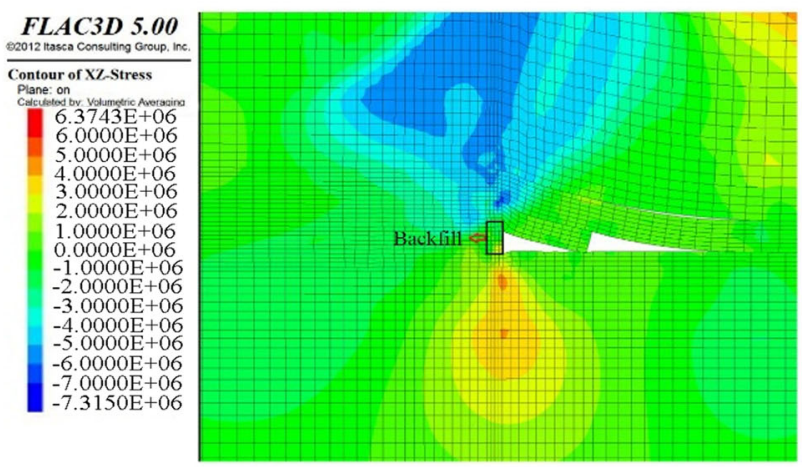

(c) Shear stress

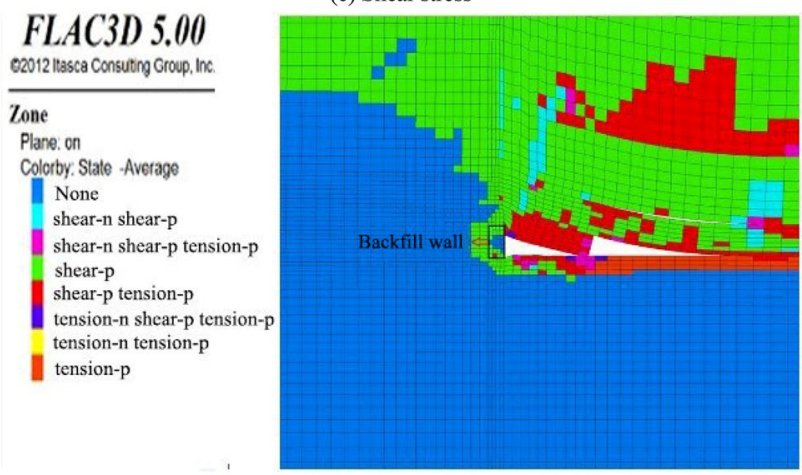

(d) Shear and tensile failure zones

Fig. 7 Stress and failure zone distributions in the rock masses surrounding the previous panel roadway after the "primary mining"

roadway due to the presence of the backfill wall. Figure 5a shows that the vertical stress distribution is significantly different between the coal side and the backfill side of the roadway. The peak of the vertical stress acting close to the top area of the backfill is $17.0 \mathrm{MPa}$, with a stress concentration coefficient of 1.61 . The stress concentration coefficient is defined as the acting stress value divided by the applied in-situ stress value at the same location. However, the peak vertical stress value of the coal side is 11.4 MPa with a stress concentration coefficient of 1.08 at a location $2 \mathrm{~m}$ laterally away from the roadway wall surface. This difference has occurred because the backfill material appearing on the left side of the roadway is stronger and stiffer than the coal seam appearing on both sides of the roadway. Therefore, the backfill is bearing more stress compared to that of the coal seam. Figure $5 b$ shows that the horizontal stress distribution is significantly different between the coal side and the backfill side of the roadway. Figure $5 \mathrm{~b}$ shows a horizontal stress concentration area $7 \mathrm{~m}$ below the roadway floor reaching a peak stress of 5.3 MPa. Another horizontal stress concentration appears just above the backfill reaching a peak of $5.2 \mathrm{MPa}$ (Fig. 5b). Figure $5 \mathrm{c}$ shows a "butterfly shape" asymmetric shear stress distribution around the roadway. On the backfill side, there are very prominent shear stress concentrations at the top and bottom side corners. On the coal side, the shear stress concentrations show more spatial spread away from the excavation into the interior rock from the corners.

\subsection{Vertical stress distribution in the backfill and in the coal seam at the floor level of the previous panel roadway and the failure zone after the "primary excavation"}

Because of the existence of the strong and stiffer backfill, the vertical stress distribution acting in the coal side (right side of the roadway) and the backfill and coal side (left side of the roadway) at the immediate floor level appears a little asymmetric (Fig. 6a). The stress acting in the backfill and coal side (left side of the roadway) at the floor level can be divided into different regions. According to the technical principle of the GPD method, the backfill was built close to the current panel side of the roadway behind the working face while the working face is advanced during the excavation of the roadway for the previous panel. Moreover, the strength and stiffness of the backfill were selected relatively higher than that of the coal. This resulted in the backfill wall bearing a higher stress than the coal. Thus, an area with the highest stress formed at the floor level under the backfill (see Fig. 6a) and reached the peak value. Although the backfill carried the highest stress, the coal could not resist that high stress. Therefore, a fracture zone appeared in the coal and coal measure rocks (Fig. 6b). This scenario resulted in a slightly downward trend of the vertical stress under the coal at the immediate floor level 


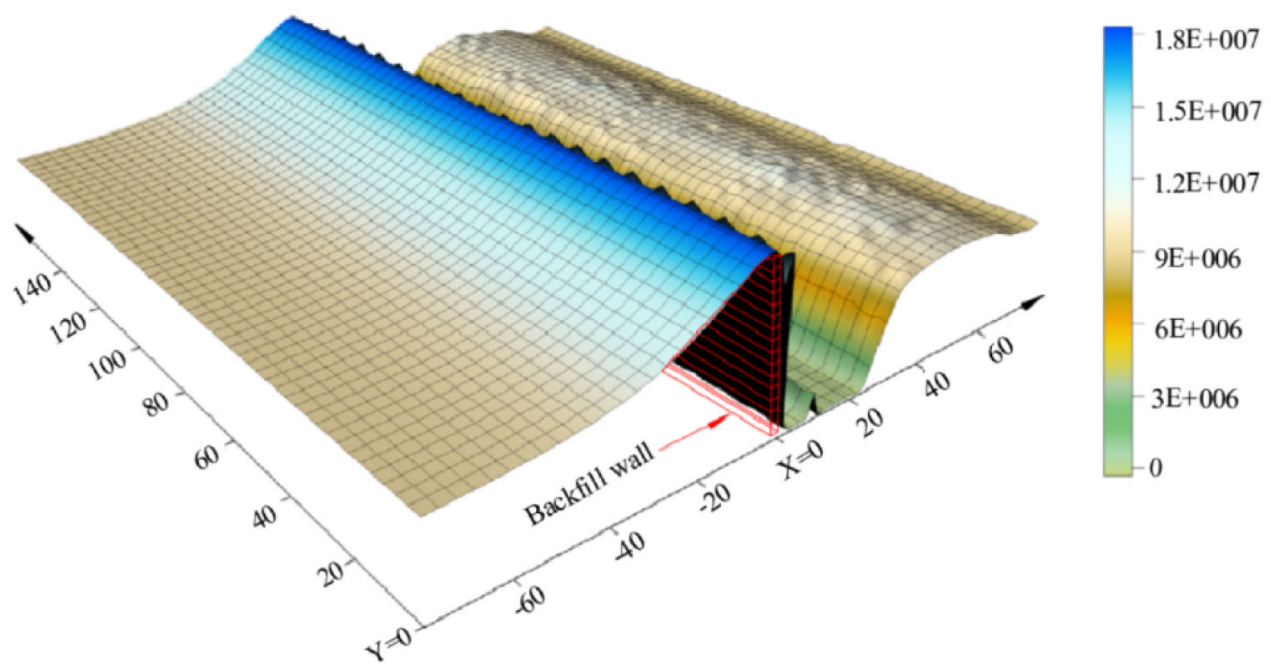

(a) Vertical stress distribution at the immediate floor level after "primary mining" (the values are given

in $\mathrm{Pa})$

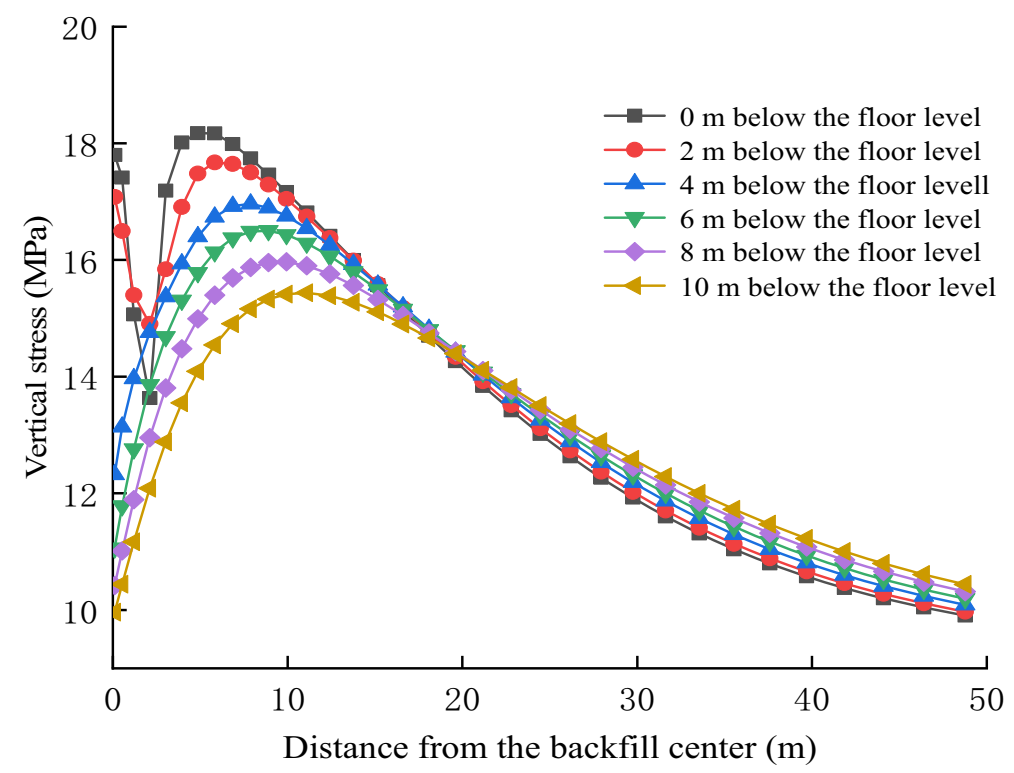

(b) Vertical stress distribution at different depths below the floor level after the "primary mining" (note the distance is in the negative $\mathrm{x}$ direction)

Fig. 8 Vertical stress distribution at and below the floor level after the "primary mining"

(Fig. 6a). The excess stresses moved laterally to both sides from the roadway to the coal measure rocks (Fig. 5a). Finally, the stress decreased with the lateral distance from the excavation to both sides of the coal measure rocks. After a certain distance away in the coal measure rocks, the stress finally decreased to the in-situ stress value.

\subsection{Stress distribution and the failure zone in the rock mass surrounding the previous panel roadway after the "primary mining"}

The modeling of the longwall face advance for the primary mining was done implementing $5 \mathrm{~m}$ incremental steps. However, the results are presented only after completing all the incremental steps to reduce the length of the paper. Figure $7 \mathrm{a}$ shows the vertical stress distribution in the backfill and around the backfill after the "primary mining" 


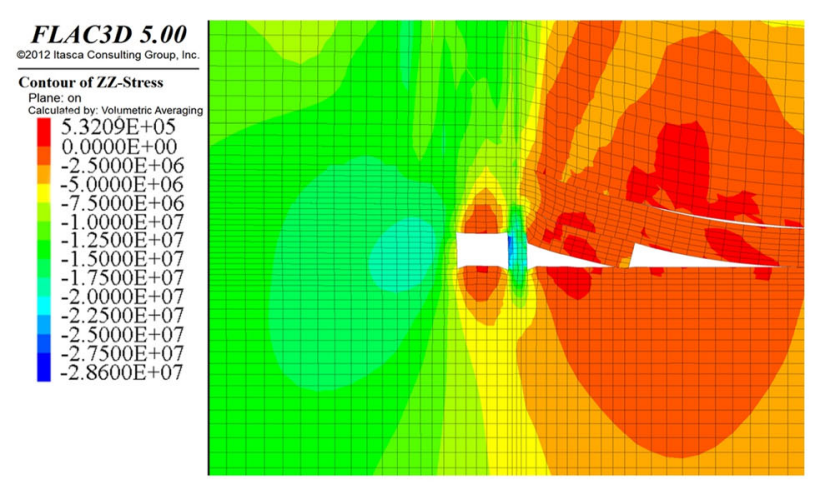

(a) Vertical stress

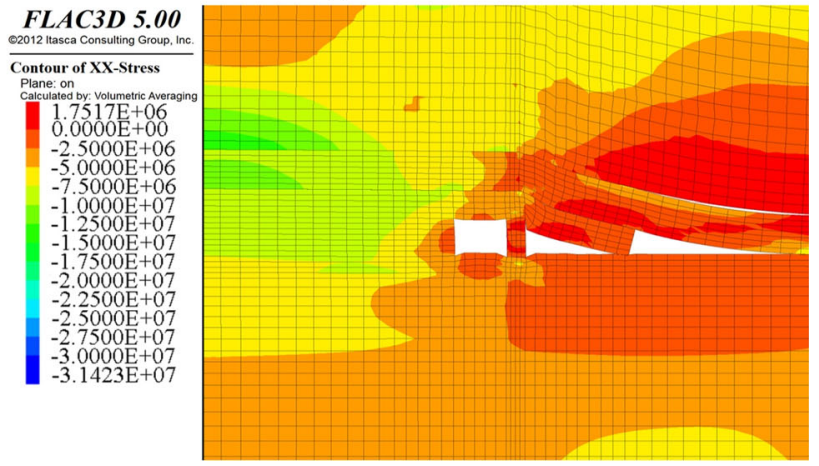

(b) Horizontal stress

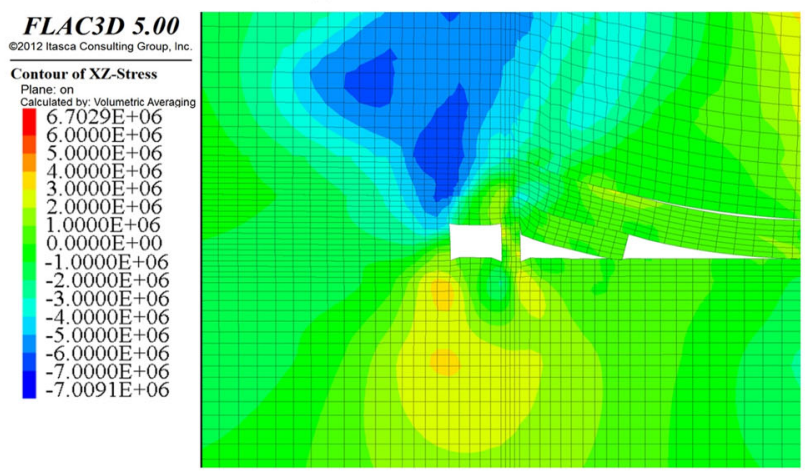

(c) Shear stress

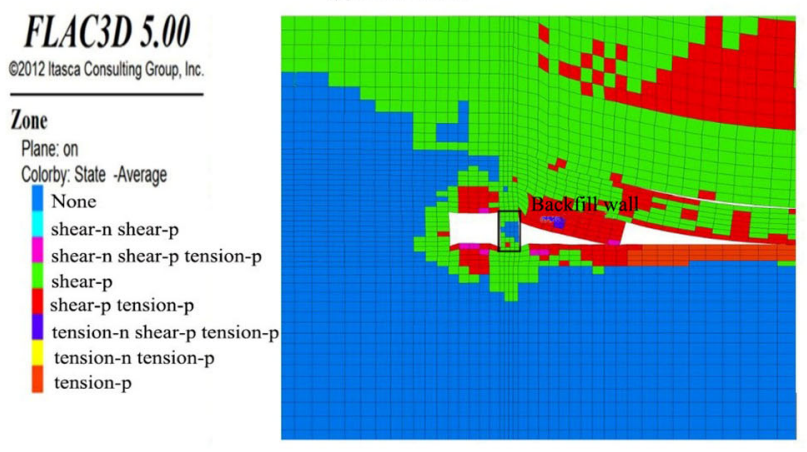

(d) Shear and tensile failure zones

Fig. 9 Stress and failure zone distributions in the rock masses surrounding the roadway of the current panel after the "secondary excavation" stage (see Fig. 2c for the "primary mining"). Either low stresses or zero stress exists in the fallen rock masses located in the previous panel area. Note that the white triangles that appear in Fig. 7 are empty areas in the goaf in the fallen rock mass. The peak vertical stress close to the top area of the backfill is $32.6 \mathrm{MPa}$ with a concentration coefficient of 3.09. The vertical stress in the coal seam has reached a peak of $23.1 \mathrm{MPa}$ with a concentration coefficient of 2.19 at a distance $2.5 \mathrm{~m}$ laterally on the left side of the backfill. From this location the vertical stress then reduces with lateral distance towards the model boundary until it reaches the in-situ stress. The horizontal stress concentrations mainly have occurred above the backfill and on the left side of the backfill in the roof rock masses (Fig. 7b). The peak horizontal stress above the backfill is 12.6 MPa. As shown in Fig. 7c, shear stress concentrations have occurred above and below areas of the backfill. At the location $2.5 \mathrm{~m}$ below the backfill, the peak shear stress is 4.4 $\mathrm{MPa}$. At the location $1.8 \mathrm{~m}$ above the backfill the peak shear stress is $6.9 \mathrm{MPa}$. These results indicate that the backfill wall increases the stability of the rock mass and the most vulnerable areas for failure in the rock mass due to primary mining are above and below the backfill wall.

Due to the disturbance by the "primary mining", all the stresses on the backfill as well as to the left of the backfill have increased significantly from the primary excavation stage due to the side abutment pressure resulting from the failures that took place in the immediate roof to the right of the backfill. The strength and stiffness of the coal is significantly less than that of the backfill wall. Therefore, a small fracture zone exists in the coal which is adjacent to the backfill (Fig. 7d). This scenario has resulted in high stresses propagating to a significant distance away from the backfill to different rock layers.

\subsection{Vertical stress distribution in the floor after the "primary mining"}

After the "primary mining", the stresses in the rock surrounding the previous panel roadway have changed extensively. Different vertical stress concentrations occurred in the backfill and coal seam at the floor level of the roadway (Fig. 8a). The stress under the backfill at the floor level turned out to be slightly less than that under the coal seam. The peak vertical stress under the backfill is 17.8 $\mathrm{MPa}$. The peak vertical stress at the floor level under the coal seam at a location of $4 \mathrm{~m}$ left of the backfill is 18.1 MPa with a concentration coefficient of 1.71. As shown in Fig. 8b, as the depth below the backfill and coal seam increases, the peak vertical stress in the floor under the backfill and coal seam decreases to different levels. The vertical stress under the backfill center decreases significantly with depth (Fig. 8b). Especially when the depth 


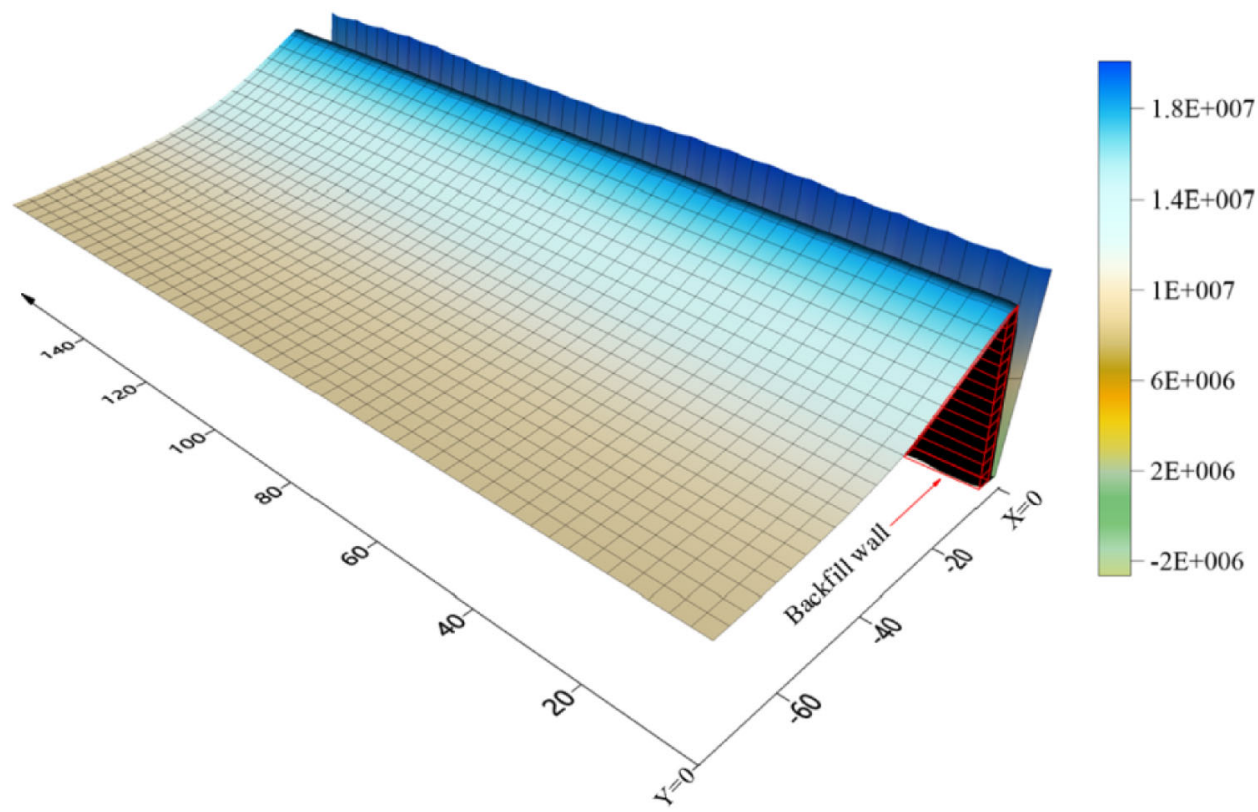

(a) Vertical stress distribution at the immediate floor level after the "secondary excavation" (the values are given in $\mathrm{Pa}$ )

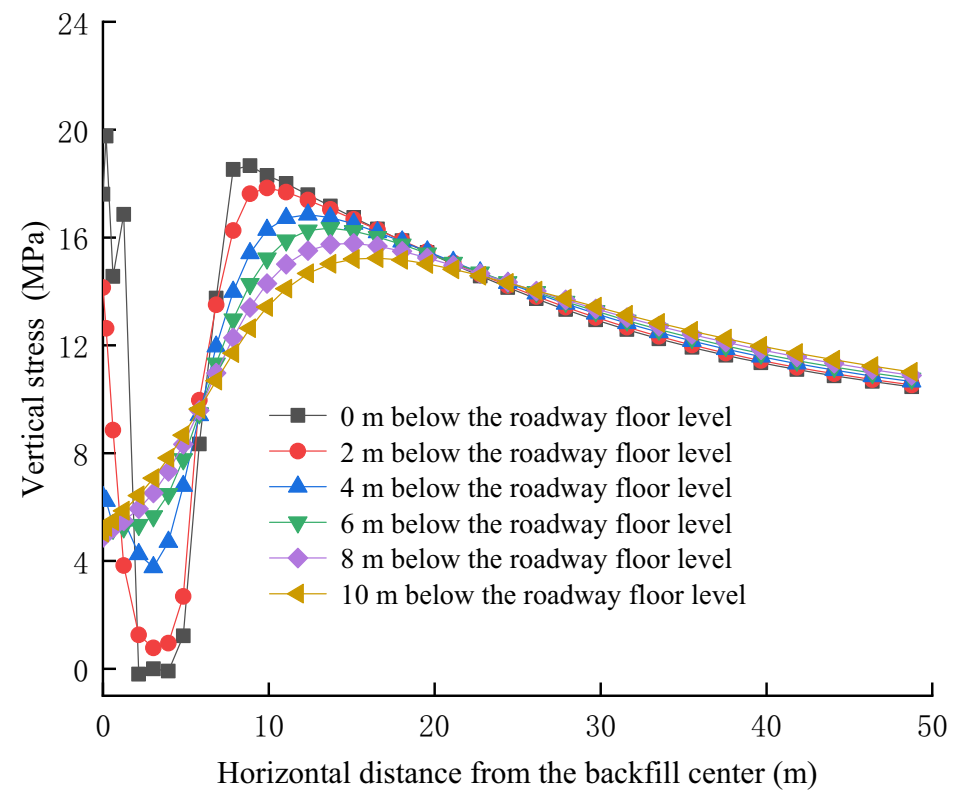

(b) Vertical stress distribution at different depths below the current panel roadway floor level after the "secondary excavation" (note the distance is in the negative $\mathrm{x}$ direction)

Fig. 10 Vertical stress distribution at and below the floor level with the horizontal distance from the backfill center after the "secondary excavation"

below the backfill center changes from 2 to $4 \mathrm{~m}$, the peak vertical stress decreases from 17.0 to $12.3 \mathrm{MPa}$.

The vertical stress in the backfill and coal seam below the floor level of the roadway can be divided into different regions. After the "primary mining", due to the high strength and stiffness of the backfill and its strong bearing capacity, an area with high stress formed immediately under the backfill. Due to the "primary mining", the side 


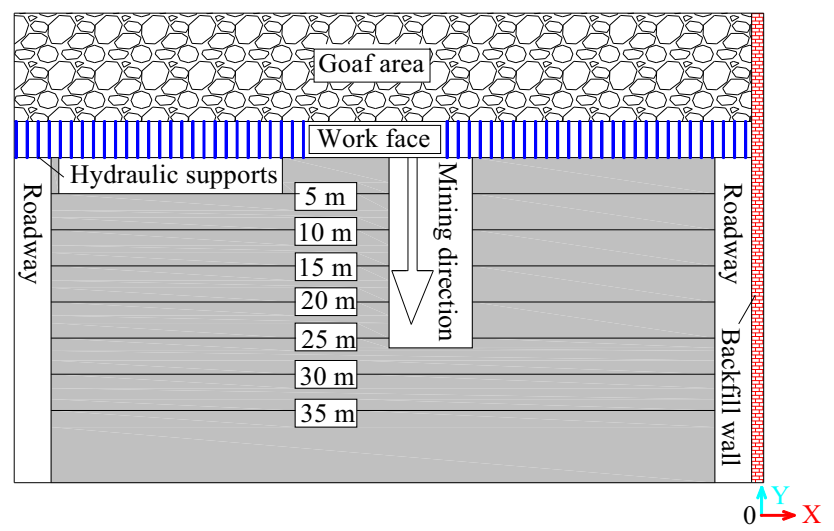

Fig. 11 Horizontal distance ahead of the working face to the unmined area

abutment pressure from the goaf of the previous panel was high. The strength and stiffness of the coal seam are less than that of the backfill. Therefore, the coal seam adjacent to the backfill was fractured in a small area due to high stress and its low bearing capacity. This resulted in the vertical stress decreasing significantly within $0-2 \mathrm{~m}$ depth under the coal seam and then increasing as the distance increases laterally away from the backfill until getting to the second peak (see Fig. 8b). Therefore, a vertical stress fluctuation occurred. Finally, the stress decreased to the insitu stress after a certain distance laterally away from the backfill. The afore-mentioned stress distribution indicates how the backfill wall takes a higher percentage of the stress and helps in reducing the stresses in the rock mass close to the mined previous panel and spreading it to locations laterally away from the backfill wall. Through this way the backfill wall increases the stability of the rock mass.

\section{Stress, deformation, and failure zone analyses around the current panel roadway during the "secondary excavation and mining"}

\subsection{Stress and failure zone distributions in the rock mass surrounding the current panel roadway after the "secondary excavation"}

It is noted that the caved goaf was not modelled. The gob was handled using the assumption that the roof stayed intact enough to lay down on the floor. The swell factor of the goaf may fill a significant proportion of the mined void and reduce the large deformations of the roof shown in the model results. Due to lack of data, modeling of this swelling may run in to high uncertainty. Therefore, the worstcase scenario was simulated to obtain the maximum stress, plastic zone, and deformation.
Figure 9a shows that there are different vertical stress concentrations under the backfill side (right side from the current panel roadway) and the coal side (left side from the current panel roadway) after the "secondary excavation" (Fig. 2d shows the secondary excavation). Note that the white triangles that appear in Fig. 9 are empty areas in the fallen rock mass. The vertical stress reached a peak of 22.1 MPa with a concentration coefficient of 2.09 at the top level of the backfill. In the coal side, the vertical stress reached a peak of $19.5 \mathrm{MPa}$ with a concentration coefficient of 1.85 at $3 \mathrm{~m}$ from the wall surface of the current panel roadway. After the secondary excavation, the peak vertical stresses acting on the backfill and on the coal side have reduced compared to the stage after the "primary mining". On the other hand, the higher stresses have propagated among a larger area in the coal side compared to the stage after the primary mining. As shown in Fig. 9b, the horizontal stress concentrations up to about $9.5 \mathrm{MPa}$ mainly appear on the coal side above the roof level of the roadway. The horizontal stress concentration also occurred at $1.5 \mathrm{~m}$ below the floor level, and the peak stress was 4.9 MPa. As shown in Fig. 9c, after the "secondary excavation" the shear stress concentrations have moved to the corners of the coal side. The peak stress above the roof level was 7.0 MPa and below the floor level was 4.5 MPa. Figure 9d shows the failure zone after the secondary excavation.

\subsection{Vertical stress distribution at and below the floor level after the secondary excavation}

The peak vertical stress acting under the backfill at the floor level (19.8 MPa) was slightly higher than that under the coal seam at the floor level (18.7 MPa) (see Fig. 10b). The location of the peak vertical stress in the coal seam has moved $3 \mathrm{~m}$ laterally compared to that after the "primary mining". The vertical stress at the roadway floor level after the "secondary excavation" can be divided into different areas. After the "secondary excavation", a relatively high vertical stress area appear under the backfill at the floor level because the backfill has high bearing capacity. The vertical stress increased as the location moved horizontally away from the roadway towards the coal side to reach a peak value first and then decreased with further increase of the horizontal distance until it reached the in-situ stress value.

As shown in Fig. 10b, the vertical stress decreases from 19.8 to $5.1 \mathrm{MPa}$ as the depth right below the backfill increases from 0 to $10 \mathrm{~m}$. On the other hand, the vertical stress right below the roadway floor increases from 0 to 7.1 $\mathrm{MPa}$ as the depth increases from 0 to $10 \mathrm{~m}$ due to stress redistribution resulting from the "secondary excavation". 


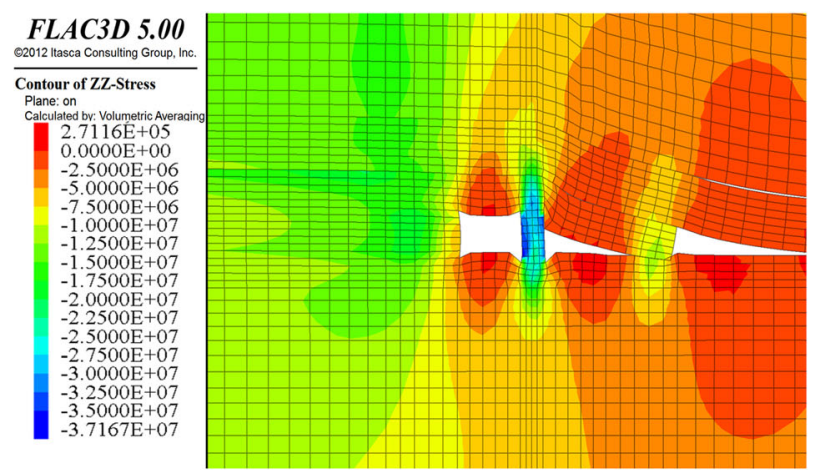

(a) $0 \mathrm{~m}$ ahead of the work face

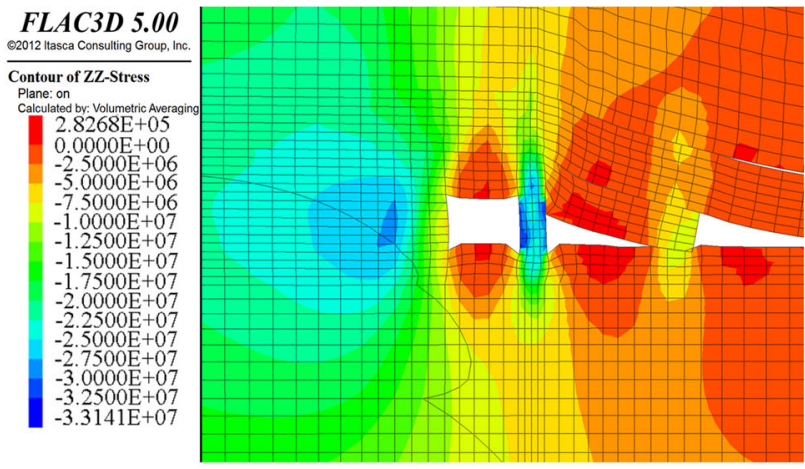

(b) $5 \mathrm{~m}$ ahead of the work face

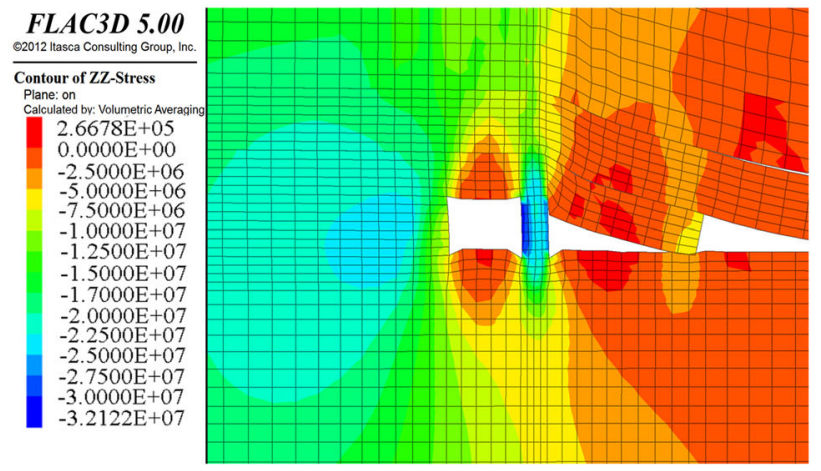

(c) $20 \mathrm{~m}$ ahead of the work face

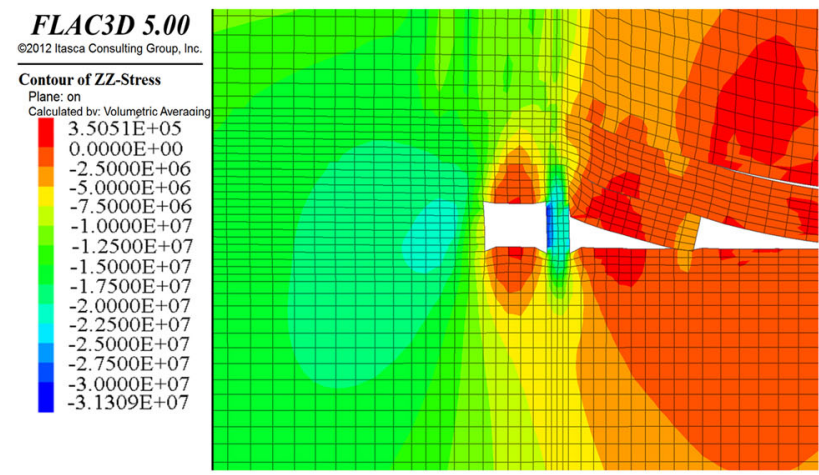

(d) $35 \mathrm{~m}$ ahead of the work face

Fig. 12 Vertical stress distribution in the rock mass surrounding the current panel roadway during the "secondary mining" at several locations ahead of the working face
The peak vertical stress on the coal side decreases from 18.7 to $15.2 \mathrm{MPa}$ as the depth increases from 0 to $10 \mathrm{~m}$. Note that the presence of the backfill wall is responsible for all the stress redistribution taking place in the rock mass due to the secondary excavation.

\subsection{Deformation characteristics of the current panel roadway after the secondary excavation}

Upon reaching a stable status after the "secondary excavation", under the influence of pressure relief and stress redistribution, the roof sag and floor heave of the roadway were 322.1 and $252.9 \mathrm{~mm}$, respectively; the horizontal displacements of the roadway wall surface of the coal side and the backfill side were 111.7 and $105.1 \mathrm{~mm}$, respectively.

\subsection{Stress distribution in the rock mass surrounding the current panel roadway during the "secondary mining"}

Figure 11 shows how the working face moves on the left side of Fig. $3 b$ during the secondary mining. The modeling of the longwall face advance for the secondary mining was done implementing $5 \mathrm{~m}$ incremental steps. As stated in the "secondary excavation" section, the caved goaf was not modelled. The gob was handled using the assumption that the roof stayed intact enough to lay down on the floor. In other words, as discussed in the "secondary excavation" section, the worst-case scenario was simulated to obtain the maximum stress, plastic zone, and deformation. As the working face progresses during the "secondary mining", the stress distribution in the rock mass surrounding the current panel roadway is mainly affected by the superposition of the front abutment pressure from the current panel and the side abutment pressure from the previous panel. Figure 12a shows the vertical stress distribution in the rock mass surrounding the current panel roadway at the working face (i.e. $0 \mathrm{~m}$ ahead of the working face). The vertical stress acting at the top part of the backfill is obviously greater than that on the coal seam. The peak vertical stress acting at the top level of the backfill is $33.2 \mathrm{MPa}$ with a concentration coefficient of 3.14 ; the peak vertical stress acting in the coal seam is $25.3 \mathrm{MPa}$ with a concentration coefficient of 2.40 . Figure $12 \mathrm{~b}$ shows the vertical stress distribution in the rock mass surrounding the current panel roadway $5 \mathrm{~m}$ ahead of the working face (see Fig. 11 for the location under consideration). The peak vertical stress above the backfill side is $31.5 \mathrm{MPa}$ with a concentration coefficient of 2.98; the peak vertical stress in the coal seam is $28.6 \mathrm{MPa}$ with a concentration coefficient of 2.71 . With the increasing horizontal distance ahead of the working face, the peak vertical stress acting at the top level of the 


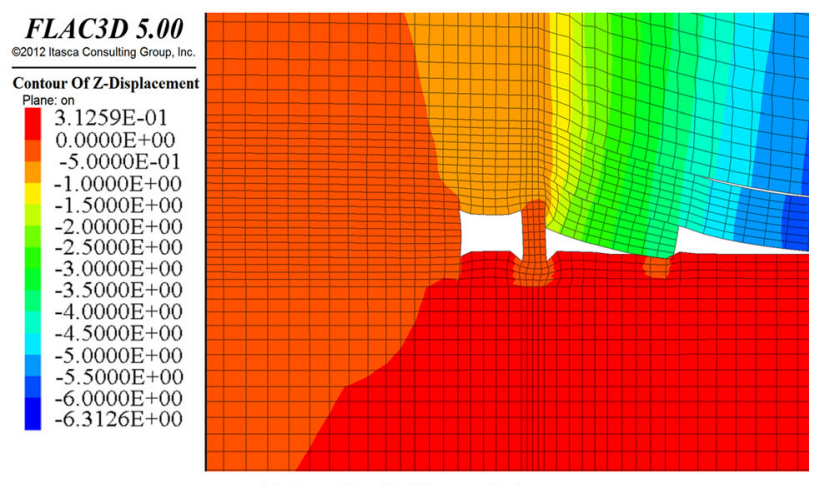

(a) $0 \mathrm{~m}$ ahead of the work face

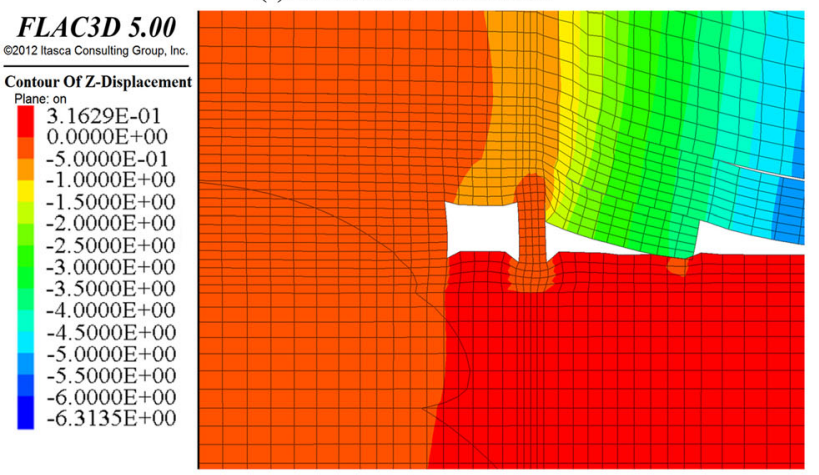

(b) $5 \mathrm{~m}$ ahead of the work face

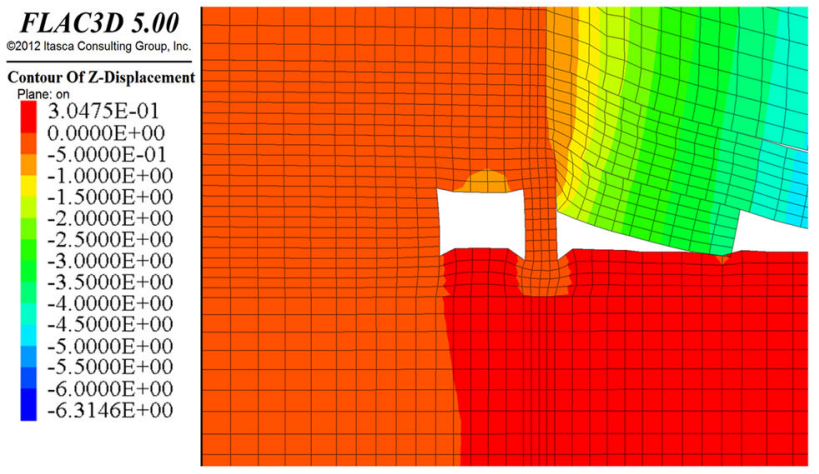

(c) $10 \mathrm{~m}$ ahead of the work face

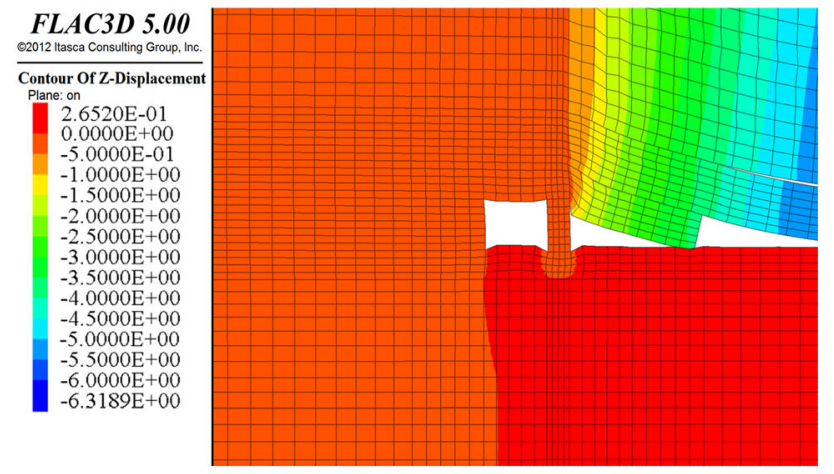

(d) $35 \mathrm{~m}$ ahead of the work face

Fig. 13 Vertical displacement distribution in the rock mass surrounding the current panel roadway during the "secondary mining" at several locations ahead of the working face backfill and in the coal seam decreased. Figure 12c, d show the distribution of the vertical stress in the rock mass surrounding the current panel roadway when the horizontal distance ahead of the working face changed to 20 and $35 \mathrm{~m}$, respectively. When the horizontal distance ahead the working face is $35 \mathrm{~m}$, the peak vertical stress acting at the top level of the backfill is $29.5 \mathrm{MPa}$ with a concentration coefficient of 2.79; the peak vertical stress acting in the coal seam is $22.5 \mathrm{MPa}$ with a concentration coefficient of 2.13 .

\subsection{Rock displacement distribution in the rock mass surrounding the current panel roadway during the "secondary mining"}

As shown in Fig. 13 and Table 2, after being disturbed by the "secondary mining", the rock mass surrounding the current panel roadway under stress redistribution showed different displacements in different directions. The deformations at the roof and floor are obviously greater than that at the two wall sides. The roof sag at the working face was the largest with $828.4 \mathrm{~mm}$; the floor heave was $310.2 \mathrm{~mm}$; the horizontal displacements at the surface of the roadway wall of the coal side and the backfill side were 222.8 and $130.8 \mathrm{~mm}$, respectively. At the working face a fracture zone appeared in the coal. Therefore, some stress redistributions occurred between 0 and $5 \mathrm{~m}$ ahead of the working face. Due to this reason all the peak deformations of the four surfaces of the roadway occurred between 0 and $5 \mathrm{~m}$ ahead of the working face. However, as the distance ahead of the working face increased from 5 to $35 \mathrm{~m}$, the deformations of the four surfaces of the roadway decreased gradually.

\subsection{Vertical stress distribution at the floor level during the "secondary mining"}

Figure 14a, b shows the peak vertical stress under the backfill wall and under the coal seam at the floor level as the distance ahead of the working face changes. The peak vertical stress under the coal seam at the floor level reached the minimum value of $15.2 \mathrm{MPa}$ at the working face. The peak vertical stress under the coal seam at the floor level increased to $27.2 \mathrm{MPa}$ at $5 \mathrm{~m}$ ahead of the working face. As the distance ahead of the working face changed from 5 to $35 \mathrm{~m}$, the peak vertical stress under the coal seam at the floor level decreased from 27.2 to $20.9 \mathrm{MPa}$. When the distance ahead of the working face is $5-20 \mathrm{~m}$, the peak vertical stress under the backfill is lower than that under the coal seam at the floor level; when the distance ahead of the working face is $25-35 \mathrm{~m}$, the peak vertical stress under the backfill at the floor level is higher than that under the coal seam. The above data showed that the backfill maintains a 
Table 2 Maximum deformations of the roadway of the current panel during the "secondary mining"

\begin{tabular}{lllll}
\hline $\begin{array}{l}\text { Distance ahead of the working face } \\
(\mathrm{m})\end{array}$ & \multicolumn{2}{l}{ Deformation $(\mathrm{mm})$} & & \\
\cline { 2 - 5 } & Roof sag & Floor heave & 222.8 & Coal side wall \\
\hline 0 & 828.4 & 310.2 & 229.3 & 130.8 \\
5 & 615.7 & 321.8 & 200.6 & 141.5 \\
10 & 541.6 & 314.3 & 176.3 & 132.1 \\
15 & 474.0 & 301.8 & 164.3 & 116.8 \\
20 & 441.3 & 292.9 & 156.9 & 111.7 \\
25 & 413.4 & 284.1 & 153.9 & 108.6 \\
30 & 381.3 & 272.9 & 139.7 & 107.1 \\
35 & 358.8 & 264.8 & & 106.1 \\
\hline
\end{tabular}

good bearing capacity during the secondary mining and provides a strong support for the stability of the roadway.

\section{Comparison of vertical stress at the floor level among different stages of the GPD Procedure}

Stress redistributes during the "primary excavation". The backfill is pre-built behind the working face while the working face is advanced during the excavation of the roadway for the previous panel and serves as the main bearing body for the previous panel roadway during the stable period. Due to the high strength and stiffness of the backfill, the vertical stress distribution at the floor level appears a little asymmetric at this stage. The highest vertical stress at the floor level of $17.0 \mathrm{MPa}$ (see curve 1 of Fig. 15), compared to the in-situ stress of $10.54 \mathrm{MPa}$, appeared immediately below the backfill wall with a concentration coefficient of 1.61 .

After the "primary mining", the peak stress of the floor moved away from the previous panel roadway into the coal seam, and there are two peak stresses at the floor level. As shown in curve 2 of Fig. 15, the peak under the coal seam is slightly higher than that under the backfill wall at the floor level, which are 18.1 and $17.8 \mathrm{MPa}$, respectively.

After the "secondary excavation", the relieved stress from current panel roadway transferred to the coal side and the backfill side. As shown in curve 3 of Fig. 15, the peak stress under the backfill is slightly higher than that under the coal seam at the floor level, which are $19.8 \mathrm{MPa}$ and 18.7 MPa, respectively.

During the "secondary mining", the stress distribution in the rock mass surrounding the current panel roadway is mainly affected by the superposition of the front abutment pressure from the current panel and the side abutment pressure from the previous panel. The vertical stress reached a peak of $27.2 \mathrm{MPa}$ with a concentration coefficient of 2.58 under the coal seam at the floor level $5 \mathrm{~m}$ ahead of the working face, while the peak vertical stress under the backfill wall at the floor level $5 \mathrm{~m}$ ahead of the working face is $24.2 \mathrm{MPa}$ with a concentration coefficient of 2.30 (see curve 4 of Fig. 15).

\section{Conclusions}

(1) Gob-side pre-backfill driving procedure has the potential to remove the shortcoming of wasting coal resources caused by the narrow coal pillar left in the roadway in gob-side entry driving along the goaf and realize non-pillar mining.

(2) The vertical stress distribution under the backfill and coal seam at the floor level turned out to be quite consistent as shown in Fig. 15 during the 4 stages of primary excavation, primary mining, secondary excavation, and secondary mining.

(3) The peak abutment pressure appears alternately in the backfill and the coal seam during the whole procedure of "twice excavation and mining" of the gob-side pre-backfill driving method. The rock mass surrounding the roadway of the gob-side entry has undergone repeated loading and unloading. The backfill has always been in a state of high stress throughout all the stages.

(4) After the "secondary excavation", the maximum values of the roof sag and floor heave were 322.1 and $252.9 \mathrm{~mm}$, respectively. During the "secondary mining", the roof sag of the roadway was 828.4 and $615.7 \mathrm{~mm}$ at the working face and $5 \mathrm{~m}$ ahead of the working face, respectively. During the secondary mining, the floor heave reached the maximum of $321.8 \mathrm{~mm}$ at $5 \mathrm{~m}$ ahead of the working face. 


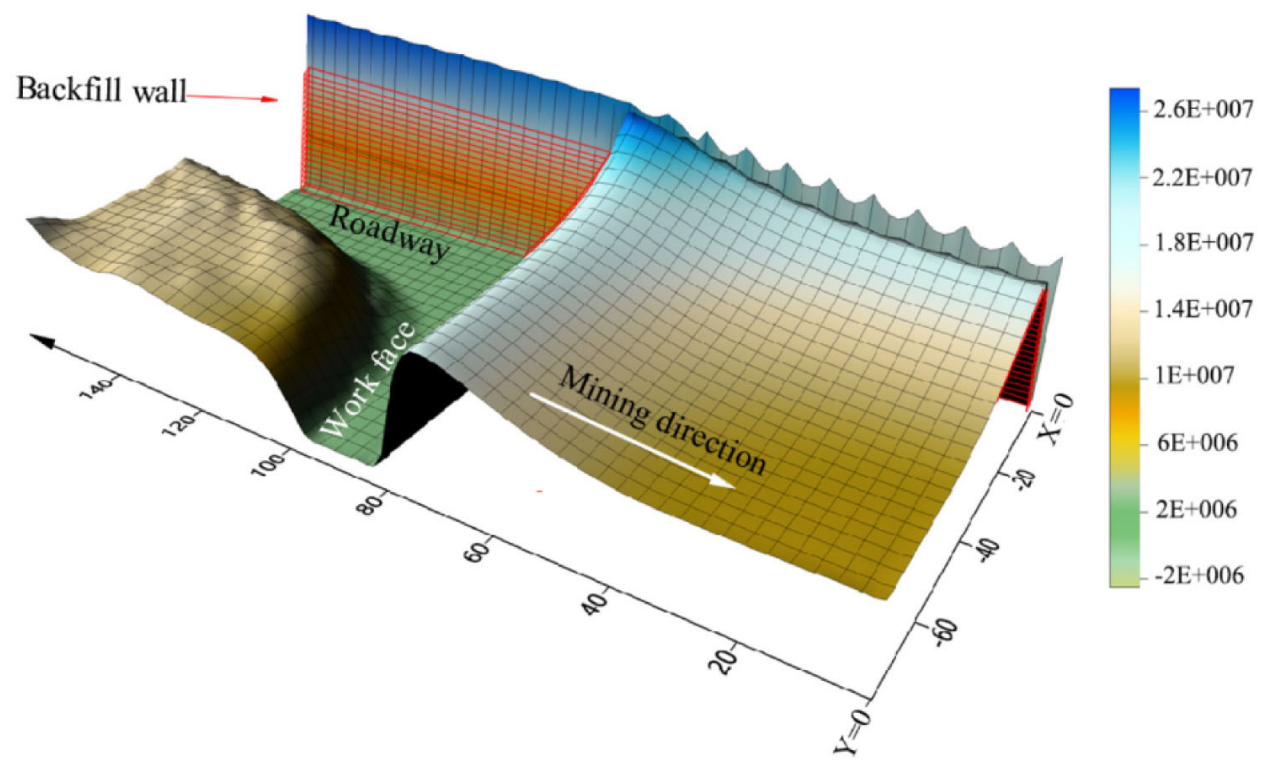

(a) Vertical stress distribution at the current panel roadway floor level at the backfill and to the left of the backfill (the values are given in $\mathrm{Pa}$ )

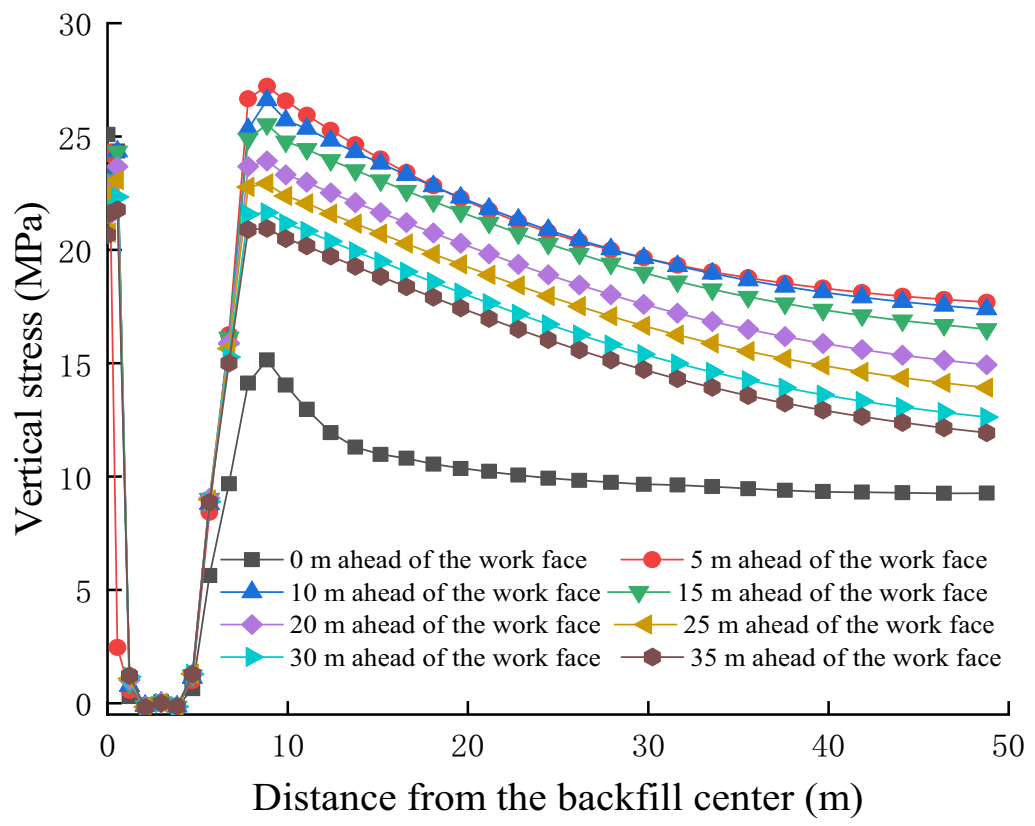

(b) Vertical stress at the floor level at sections located at different horizontal distances ahead of the working face

Fig. 14 Vertical stress distribution at the floor level during the "secondary mining"

(5) The backfill maintained a good bearing capacity in all stages of excavation and mining and provided a strong support for the stability of the roadway.

(6) The scenario presented in the paper does not cover all possible scenarios for the conducted case study.
For a particular mine, the results would vary with the size of the roadways and the backfill wall as well as on the backfill material properties, coal and coal measure rock properties, in-situ stress system, and on the operation of the longwall mining procedure. 


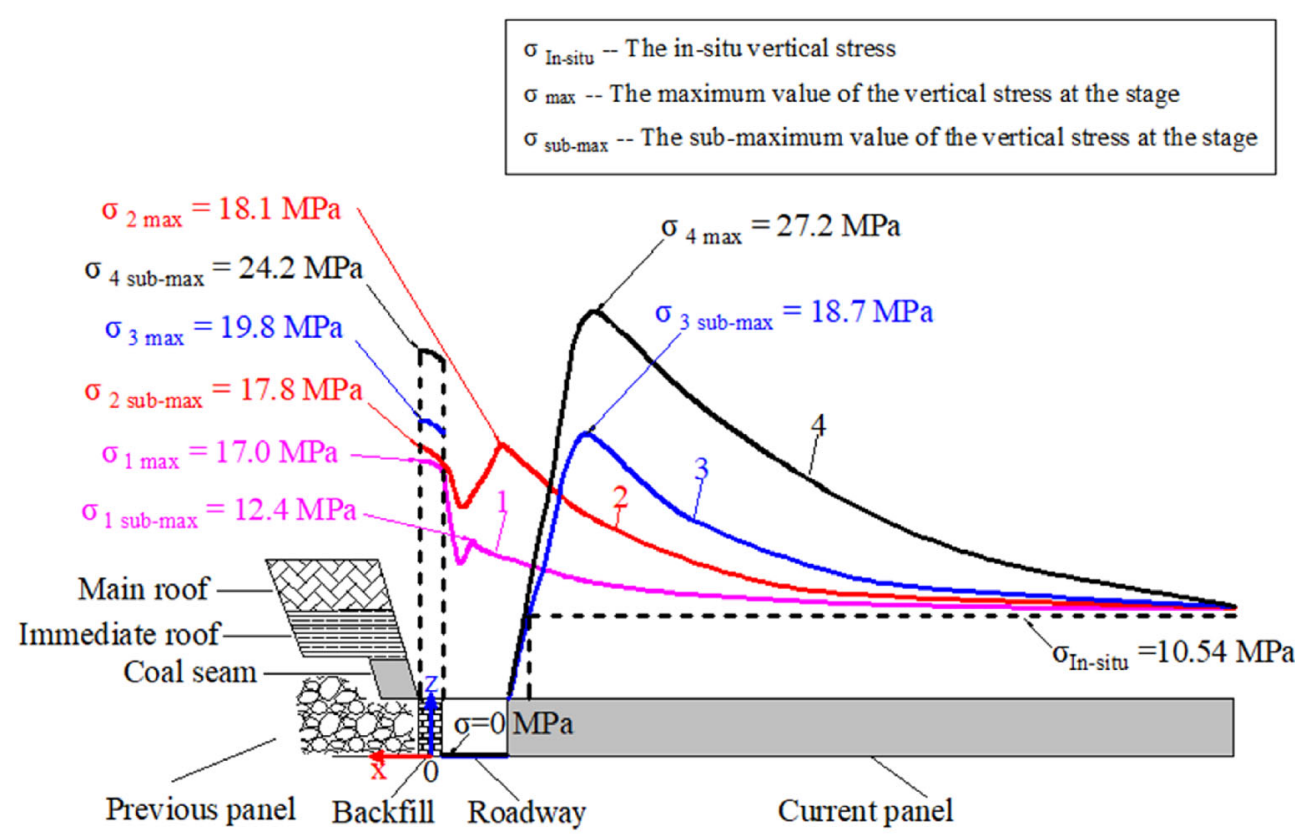

1 - Vertical stress distribution at the floor level after the "primary excavation"; 2 - Vertical stress distribution at the floor level after the "primary mining"; 3 - Vertical stress distribution at the floor level after the "secondary excavation"; 4 - Vertical stress distribution at the floor level $5 \mathrm{~m}$ ahead of the work face during the "secondary mining"; Note that the constructed backfill was included in the "primary excavation analysis; Note that the current panel roadway shown in the figure was excavated at the "secondary excavation"-it did not exist during the "primary excavation" and "primary mining".

Fig. 15 Vertical stress distribution at the floor level in the negative $X$ direction from the backfill after different excavation and mining stages. 1-Vertical stress distribution at the floor level after the "primary excavation"; 2-Vertical distribution at the floor level after the "primary mining"; 3-Vertical stress distribution at the floor after the "secondary excavation"; 4-Vertical stress distribution at the floor level $5 \mathrm{~m}$ ahead of the face during the "secondary mining"; Note that the constructed backfill was included in the "primary excavation analysis"; Note that the current panel roadway shown in the figure was excavated at the "secondary excavation"-it did not exist during the "primary excavation" and "primary mining"

Therefore, it is important to perform sufficient stress, deformation, and failure zone sensitivity analyses by varying the afore-mentioned parameters before one decides on implementing the gob-side pre-backfill driving procedure to a mine.

(7) The results of the conducted study provide scientific insight for engineering practice of gob-side prebackfill driving procedure.

Acknowledgements The conducted research was financially supported by the National Natural Science Foundation of China (51604126, 51974293), and the Natural Science Foundation of Jiangsu Province (BK20180658). The financial support the third author received through the Distinguished Foreign Expert Talent Program Funding from the Chinese Government and Jiangxi Province are also gratefully acknowledged.

Funding This research was supported by the National Natural Science Foundation of China (51604126, 51974293), the Natural Science
Foundation of Jiangsu Province (BK20180658), and the Distinguished Foreign Expert Talent Program funding from the Chinese Government and the Jiangxi Province.

Data availability The data appearing in the manuscript can be made available by contacting the first author of the manuscript after publishing the paper.

Code availability Authors have no ownership of the computer code used in this paper. It should be purchased from Itasca Consulting Company.

\section{Declaration}

Conflict of interest The authors declare that they have no known competing financial interests or personal relationships that could have appeared to influence the work reported in this paper.

Open Access This article is licensed under a Creative Commons Attribution 4.0 International License, which permits use, sharing, adaptation, distribution and reproduction in any medium or format, as long as you give appropriate credit to the original author(s) and the 
source, provide a link to the Creative Commons licence, and indicate if changes were made. The images or other third party material in this article are included in the article's Creative Commons licence, unless indicated otherwise in a credit line to the material. If material is not included in the article's Creative Commons licence and your intended use is not permitted by statutory regulation or exceeds the permitted use, you will need to obtain permission directly from the copyright holder. To view a copy of this licence, visit http://creativecommons. org/licenses/by/4.0/.

\section{References}

Chang Q, Tang W, Xu Y, Zhou H (2018) Research on the width of filling body in gob-side entry retaining with high-water materials. Int J Min Sci Technol 28(3):519-524. https://doi.org/10. 1016/j.ijmst.2017.12.016

Fan K, Liang H, Ma C, Zang C (2014) Non-harmonious deformation controlling of gob-side entry in thin coal seam under dynamic pressure. J Rock Mech Geotech Eng 6(3):269-274. https://doi. org/10.1016/j.jrmge.2014.05.001

Feng GR, Wang PF (2020) Stress environment of entry driven along gob-side through numerical simulation incorporating the angle of break. Int J Min Sci Technol 30(2):189-196. https://doi.org/10. 1016/j.ijmst.2019.03.003

Han CL, Zhang N, Xue JH, Kan JG, Zhao YM (2019) Multiple and long-term disturbance of gob-side entry retaining by grouped roof collapse and an innovative adaptive technology. Rock Mech Rock Eng 52:2761-2773. https://doi.org/10.1007/s00603-018$1612-0$

Hua XZ (2006) Development status and improved proposals on gobside entry retaining support technology in China. Coal Sci Technol 34(12):78-81. https://doi.org/10.3969/j.issn.0253-2336. 2006.12.027

Huang B, Liu J, Zhang Q (2018) The reasonable breaking location of overhanging hard roof for directional hydraulic fracturing to control strong strata behaviors of gob-side entry. Int J Rock Mech Min Sci 103:1-11. https://doi.org/10.1016/j.ijrmms.2018. 01.013

Jiang PF, Zhang J, Hu B (2016) Mechanical and deformation characteristics of gob-side entry retaining surrounding rock and support methods. J Min Saf Eng 33(1):56-62. https://doi.org/10. 13545/j.cnki.jmse.2016.01.009 (in Chinese)

Ju Y, Zhu Y, Xie HP, Nie XD, Zhang Y, Lu C, Gao F (2019) Fluidized mining and in-situ transformation of deep underground coal resources: a novel approach to ensuring safe, environmentally friendly, low-carbon, and clean utilisation. Int J Coal Sci Technol 6(2):184-196. https://doi.org/10.1007/s40789-0190258-1

Kang HP, Lin J, Zhang X, Wu YZ (2010) In-situ stress measurements and distribution laws in lu' an underground coal mines. Rock Soil Mech 31: 827-831+844. https://doi.org/10.3969/j.issn.10007598.2010.03.029 (in Chinese)

Liu Q, Wang Q (2017) China's energy revolution-reform of supplyside and structural optimization (2017-2050). Int Pet Econ 25(08): $1-14$ (in Chinese)

Liu ZH, Gao Q, Hua XZ, Wu YH, Fu KL, Liu Y (2009) Aging characteristics of wall rock control in roadway driving along goaf. J Min Saf Eng 26(4):465-469. https://doi.org/10.3969/j. issn.1673-3363.2009.04.015 (in Chinese)

Mo S, Tutuk K, Saydam S (2019) Management of floor heave at Bulga underground operations-a case study. Int J Min Sci Techol 29(1):73-78. https://doi.org/10.1016/j.ijmst.2018.11.015

Sajjad A, Hossein J, Gholamreza S (2019) Prediction of face advance rate and determination of the operation efficiency in retreat longwall mining panel using rock engineering system. Int J Coal Sci Technol 6(3):419-429. https://doi.org/10.1007/s40789-0190245-6

Tan YL, Yu FH, Ning JG, Zhao TB (2015) Design and construction of entry retaining wall along a gob side under hard roof stratum. Int J Rock Mech Min Sci 100(77):115-121. https://doi.org/10. 1016/j.ijrmms.2015.03.025

Tan YL, Yu FH, Ning JG, Zhao TB (2016) Adaptability theory of roadside support in gob-side entry retaining and its supporting design. J China Coal Soc 41(2):376-382. https://doi.org/10. 13225/j.cnki.jccs.2015.1385

Tang SB, Tang CA (2012) Numerical studies on tunnel floor heave in swelling ground under humid conditions. Int J Rock Mech Min Sci 55:139-150. https://doi.org/10.1016/j.ijrmms.2012.07.007

Wang WY, Gao MZ (2019) Study on characteristics of deformation and stress distribution of gob-side entry retaining in the ultradeep mine. Chin J Rock Mech Eng 38(S1):2955-2963. https:// doi.org/10.13722/j.cnki.jrme.2017.1110

Wang M, Bai JB, Wang XY, Xu Y, Guo YH, Cao JL (2012) The surrounding rock deformation rule and control technique of the roadway driven along goaf and heading for adjacent advancing coal face. J Min Saf Eng 29(2):197-202. https://doi.org/10.3969/ j.issn.1673-3363.2012.02.009

Wang Q, He MC, Yang J, Gao H, Jiang B, Yu H (2018) Study of a nopillar mining technique with automatically formed gob-side entry retaining for longwall mining in coal mines. Int $\mathrm{J}$ Rock Mech Min Sci 110:1-8. https://doi.org/10.1016/j.ijrmms.2018. 07.005

Wang JC, Wei WJ, Zhang JW (2020) Theoretical description of drawing body shape in an inclined seam with longwall top coal caving mining. Int J Coal Sci Technol 7(1):182-195. https://doi. org/10.1007/s40789-019-00286-z

Wu R, Xu JH, Zhao K, Li HG (2017) Deformation characteristics and control of the surrounding rock in roadways with pre-backfill instead of the pillar in fully mechanized panels. J Min Saf Eng 34(02):221-227. https://doi.org/10.13545/j.cnki.jmse.2017.02. 004 (in Chinese)

Wu R, He QY, Oh J, Li ZC, Zhang CG (2018) A New gob-side entry layout method for two-entry longwall systems. Energies 11(8):2084. https://doi.org/10.3390/en11082084

Wu BW, Wang XY, Bai JB, Wu WD, Zhu XX, Li GD (2019) Study on crack evolution mechanism of roadside backfill body in gobside entry retaining based on UDEC trigon model. Rock Mech Rock Eng 52:3385-3399. https://doi.org/10.1007/s00603-01901789-6

Xu Y, Zhou H, Bai JB, Chen J (2015) Characteristics and control method of floor heave in gob-side entry retaining. Chin J Rock Mech Eng 34:4235-4243. https://doi.org/10.13722/j.cnki.jrme. 2015.1023 (in Chinese)

Yang J, He M, Cao C (2019) Design principles and key technologies of gob side entry retaining by roof pre-fracturing. Tunn Undergr Sp Technol 90:309-318. https://doi.org/10.1016/j.tust.2019.05. 013

Yuan L (2017) Scientific conception of precision coal mining. J China Coal Soc 42(1):1-7. https://doi.org/10.13225/j.cnki.jccs.2016. 1661

Yuan L (2018) Strategies of high efficiency recovery and energy saving for coal resources in China. J China Univ Min Technol 20(01):3-12. https://doi.org/10.3969/j.issn.1009-105x.2018.01. 001 (in Chinese)

Zha WH, Shi H, Liu S, Kang CH (2017) Surrounding rock control of gob-side entry driving with narrow coal pillar and roadway side sealing technology in Yangliu Coal Mine. Int J Min Sci Technol 27(5):819-823. https://doi.org/10.1016/j.ijmst.2017.07.023

Zhang DS, Wang HS, Ma LQ (2010) Two-step gob-side entry driving technology of pre-build artificial side substitute for narrow coal 
pillar. J China Coal Soc 35(10):1589-1593. https://doi.org/10. 1016/S1876-3804(11)60004-9

Zhang ZZ, Bai JB, Chen Y, Yan S (2015) An innovative approach for gob-side entry retaining in highly gassy fully-mechanized longwall top-coal caving. Int J Rock Mech Min Sci 80:1-11. https://doi.org/10.1016/j.ijrmms.2015.09.001

Zhao KG, Li YP (2018) Analysis and development suggestion for coal resources safety in China. Coal Eng 50(10):185-189. https://doi.org/10.11799/ce201810043 (in Chinese)
Zhu Z, He MC, Wang Q, Gao YB, Wang YJ (2019) An innovative non-pillar mining method for gateroad formation automatically and its application in Ningtiaota coal mine. J China Univ Min Technol 48(1):46-53. https://doi.org/10.13247/j.cnki.jcumt. 000965 (in Chinese) 